\title{
Molecular Sequence of Events and Signaling Pathways in Cerebral Metastases
}

\author{
JARED B. COOPER, JENNIFER S. RONECKER, MICHAEL E. TOBIAS, AVINASH L. MOHAN, \\ VIRANY HILLARD, RAJ MURALI, CHIRAG D. GANDHI, MEIC H. SCHMIDT and MEENA JHANWAR-UNIYAL
}

Department of Neurosurgery, WMCH/New York Medical College, Valhalla, NY, U.S.A.

\begin{abstract}
Brain metastases are the leading cause of morbidity and mortality among cancer patients, and are reported to occur in about $40 \%$ of cancer patients with metastatic disease in the United States of America. Primary tumor cells appear to detach from the parent tumor site, migrate, survive and pass through the blood brain barrier in order to establish cerebral metastases. This complex process involves distinct molecular and genetic mechanisms that mediate metastasis from these primary organs to the brain. Furthermore, an interaction between the invading cells and cerebral milieu is shown to promote this process as well. Here, we review the mechanisms by which primary cancer cells metastasize to the brain via a mechanism called epithelial-to-mesenchymal transition, as well as the involvement of certain microRNA and genetic aberrations implicated in cerebral metastases from the lung, breast, skin, kidney and colon. While the mechanisms governing the development of brain metastases remain a major hindrance in treatment, understanding and identification of the aforementioned molecular pathways may allow for improved management and discovery of novel therapeutic targets.
\end{abstract}

Brain metastases are a leading cause of morbidity and mortality among cancer patients, and are reported to occur in about $40 \%$ of cancer patients in the United States of America (USA), with an incidence approaching 170,000/year in the USA $(1,2)$. Primary organ tumors that have the

This article is freely accessible online.

Correspondence to: Dr. Meena Jhanwar-Uniyal, 19 Skyline Drive, Department of Neurosurgery, New York Medical College, Valhalla, NY 10595, U.S.A. Tel: +1 9145942513, e-mail: meena_jhanwar@nymc.edu

Key Words: Brain metastases, epithelial-to-mesenchymal transition, microRNA, genetic markers, signaling pathway, review. greatest propensity to metastasize to the brain include lung (50-60\%), breast (15-20\%), skin (5-10\%), kidney $(7 \%)$ and colon cancers $(4-6 \%)(3,4)$. In general, the median survival following a diagnosis of cerebral metastases is between 2 and 25 months, depending on the origin of the primary tumor and time of diagnosis $(5,6)$. The diversity of these primary sites suggests the possibility of a common mechanism by which these tumors metastasize to the brain. Moreover, a complex interaction exists with the cerebral microenvironment that results in a propensity for these tumors to disseminate to the central nervous system (CNS).

For many cancer patients, the diagnosis of metastasis to the brain can be devastating. In some cases, only supportive care is recommended. However, several studies show that there is a survival benefit to combined treatment of surgical resection and radiation therapy. For example, a review of cerebral metastasis from gastroesophageal cancer showed a survival advantage in patients treated with resection of the metastatic lesion followed by radiation, which included whole-brain radiation therapy or stereotactic radiosurgery (7). They specifically reported a patient with a cerebellar metastasis diagnosed five months after treatment for his primary disease who had no recurrence five years after undergoing resection of the brain metastasis followed by stereotactic radiosurgery. Furthermore, Karagkiouzis et al., reported that in patients with solitary extrapulmonary metastasis from NSCLC who underwent surgical resection of the primary tumor as well as the solitary metastasis had improved survival, especially if the metastasis was not present within less than six months from diagnosis (8). Despite current advances in treatment for metastatic lesions, including surgical resection, chemotherapy and radiation, there is limited benefit in the form of prolonged survival. As such, improvement in therapeutic options for metastatic brain lesions remains an unmet necessity.

Tumor cells bypass multiple checkpoints in order to establish metastasis to the brain. A complex mechanism 
termed epithelial-to-mesenchymal transition (EMT), which is governed by a sequence of multiple signaling pathways, appears to govern this process. In addition, the presence of cancer stem cells (CSC) within the tumor may contribute to this process and aid in evading current chemotherapeutics. Moreover, a distinctive genetic signature is associated with a propensity for cerebral metastases unique to discrete primary sites. In this review, we discuss the molecular process and genetic markers associated with the development of cerebral metastases, with particular focus on the five primary tumor sites, namely lung, breast, skin, colon and kidney, having the most propensity for metastasizing to the brain.

\section{Epithelial-to-mesenchymal Transition in Cerebral Metastasis}

In general, commencement of metastasis begins with detachment of primary cancer cells from the tumor mass. This is followed by invasion through the basement membrane and intravasation into the systemic hematologic and lymphatic circulation. The circulating tumor cells then extravasate through gaps in endothelial cells at a distant site, where they form a secondary lesion. This complex sequence of metastasis requires a sophisticated process, referred to as EMT. The process of EMT is well recognized as it plays an important role in embryogenesis and later in severe wound healing. EMT is characterized by the loss of cellular apical-basal polarity, resulting in the formation of a cell with mesenchymal properties, allowing for dissociation of cell-cell interactions and migratory potential. Upon reaching the secondary site, the cells appear to undergo a reversal process termed mesenchymal-to-epithelial transition (MET) by which the tumor cells regain phenotypic and genotypic properties of the primary tissue. This process is analogous in the development of metastatic tumors. Recent studies have shown that the process of EMT can propel cancer cells into a CSC-like state allowing them to acquire a mesenchymal phenotype, suggesting a functional link between CSCs and the metastatic process (9). Tam and Weinberg have attempted to elucidate a detailed and complex transcriptional process that governs the steps of EMT and its reversal mechanism MET (10). The canonical EMT/MET processes are characterized by complex genetic alteration that allows epithelial or mesenchymal cells to be distinguished by expression of a number of classical markers (11). Well-recognized epithelial markers include cadherins and tight junction proteins such as E-cadherin. Mesenchymal markers include the extracellular matrix component fibronectin and the intermediate filament protein vimentin. During embryogenesis, EMT is governed by a number of diverse growth factors including fibroblast growth factor (FGF), platelet derived growth factor (PDGF), epidermal growth factor (EGF) and transforming growth factor beta (TGF $\beta$ ), leading to activation of various receptor tyrosine kinases (RTKs) (12). These mechanisms are shown to reappear during the metastatic process via EMT, where TGF $\beta$ plays a pivotal role.

Activation of the TGF $\beta$ pathway results in translocation of Smad transcription factor proteins into the nucleus where they interact with other transcription factors to activate or repress genes involved in EMT (13). TGF $\beta$ has a direct effect on EMT by down-regulation of epithelial and up-regulation of mesenchymal markers, through activation of a number of transcription factors including zinc finger SNAI1 (Snail), zinc finger SNAI2 (Slug), zinc finger E-box binding homeobox 1 (ZEB1), zinc finger E-box homeobox 2 (ZEB2), and twist family bHLH transcription factor 1 (TWIST), that are recognized as master regulators of this process (14). Under the influence of TGF $\beta$, transcriptional repression of the transmembrane adhesion protein E-cadherin occurs, which emerged as a fundamental regulator in the process of tumor progression and EMT $(12,15,16)$. Notably, transcription factors Snail, Slug and ZEB1/2 are recognized as key regulators in E-cadherin repression, in addition to their roles in induction of mesenchymal genes $(12,16)$. GATA1, a known repressor of E-cadherin, was found to be up-regulated in samples of lung-derived brain metastases, suggesting a role for E-cadherin modulation in the process of cerebral dissemination (17). Commonly, overexpression of the HER2 gene in breast cancer is shown to be associated with TGF $\beta$ signaling, leading to the activation of Snail, Slug and ZEB1 (18). Suppression of this signaling by cucurbitacin B in mouse models led to reversal of the EMT process and reduction of brain metastases (18). Moreover, a link between TWIST and other regulators of EMT such as Snail, Slug and ZEB has been seen (16). Induction of ZEB1 by TGF $\beta$ was dependent on cooperation between Snail and TWIST in mammary epithelial cells undergoing EMT (19). TWIST, a member of the helix-loop-helix family of factors, is predominantly expressed during embryogenesis in neural crest cells. It is believed that TWIST maintains roles in suppressing expression of E-cadherin, occludins and claudin-7, and induction of pro-invasive and mesenchymal genes (16, 20-22). High TWIST expression was observed in metastatic melanoma and was considered as an independent marker of poor prognosis in these patients (23). Similar findings are reported in highly invasive ductal carcinoma, prostate cancer, esophageal squamous cell carcinoma and hepatocarcinomas (24-29). A recent study described an increased expression of EMT markers Snail and TWIST present in samples of brain metastases from lung, breast, colon and renal primary tumors (17). Similar to the TGF $\beta$ signaling pathway, downstream effectors of EGFR, namely signal transducer and activator of transcription 3 (STAT3), is linked to the activation of TWIST and subsequent promotion of EMT. STAT3 is a member of a family of latent transcription factors that are activated by cytokines and growth factors (30) and is constitutively 
activated in many cancers. The link between STAT3 and TWIST has been suggested in invasive breast (31), hepatocellular (32) and gastric cancers (33). Increased STAT3 activity was also evident in models of melanoma-derived brain metastases, which display increased activity of STAT3, relative to primary melanoma cells (34). Furthermore, an inhibition of STAT3 may suppress the cerebral metastases as shown in an animal model of malignant melanoma (34).

TGF $\beta$ also elicits signaling responses via non-Smad pathways, which are thought to complement Smad signaling in producing an effective EMT response. Activation of nonSmad signaling pathways relies on direct interactions between effector molecules and TGF $\beta$ RI and/or TGF $\beta$ RII receptors (13). The intersection of TGF $\beta$-mediated EMT activation and non-Smad signaling is thought to occur under the influence of other signaling pathways associated with Erk MAP kinases, Rho GTPases and the PI3 Kinase/AKT pathway $(13,35,36)$.

MAP kinase pathways appeared to play a significant role in TGF $\beta$-mediated EMT, as studies have revealed downregulation of E-cadherin and up-regulation of $\mathrm{N}$-cadherin and matrix metalloproteinase expression in response to MEK/Erk MAP kinase activation $(13,37-41)$. Interestingly, the MAPK pathway is also known to be activated by mutations in the oncogene $B R A F^{\mathrm{V} 600 \mathrm{E}}$, commonly associated with melanoma, with a higher tendency for metastasizing to the brain (42). In fact, a recent study demonstrated inhibition of melanoma brain metastasis cell lines harboring a $B R A F^{\mathrm{V} 600 \mathrm{E}}$ mutation, using the MAPK inhibitor vemurafenib (42). Furthermore, downregulation of the PI3K/Akt pathway using temsirolimus, a mechanistic target of rapamycin (mTOR) inhibitor, reduced proliferation of melanoma-derived brain metastases harboring mutations in the PTEN tumor suppressor gene (42). Additionally, TGF $\beta$ is shown to activate PI3K, which results in a subsequent activation of the Akt kinase via integrins (4347). In fact, $\alpha v$ integrin levels in cancer cell are shown to be positively correlated with the number of brain metastasis as well with the rate of occurrence. A recent study points to the role of $\alpha v$ integrin in promoting brain metastases in cancer cells and may be involved in early steps in the metastatic process, such as adhesion to brain vasculature and motility. Therefore, targeting $\alpha v$ integrin with intetumumab could provide clinical benefit in treating cancer patients with brain metastases (48). Specific genetic variations in the genes for PI3K, PTEN, AKT and mTOR have been identified as predictors of brain metastases in a model of NSCLC (49). Importantly, the PI3K/Akt pathway facilitates downstream signaling that is involved in the promotion of EMT, cell migration and cell survival $(13,43,50)$. As such, inhibitors of this pathway have been found to hinder TGF $\beta$-mediated Ecadherin down-regulation, thereby halting the process of EMT $(43,51,52)$. Specifically, two multiprotein complexes of mTOR, mTORC1 and mTORC2 have been implicated in coordinating various cellular functions associated with EMT
$(53,54)$. Consistent with these findings, increased mTOR signaling has been linked to TGF $\beta$ activity via mTORC1 and phosphorylation of p70S6K and 4E-BP1, which subsequently result in increased protein synthesis and cell size (51). Studies of metastatic liver (55) and colorectal cancer (56) have highlighted mTOR as an emerging target of interest in regulating tumorigenesis and metastasis. With respect to cerebral metastases, components of the mTOR signaling pathway are shown to be up-regulated in models of metastatic breast cancer and suppression of these markers resulted in significantly diminished metastatic potential $(57,58)$. Moreover, silencing of mTOR pathway components suppresses E-cadherin expression and enhances expression of the mesenchymal marker vimentin, suggesting an important regulatory role for mTOR in the processes of both EMT and MET (57).

RhoGTPases are also known regulators of cell migration, gene regulation and cytoskeleton organization (13). TGF $\beta$ regulates Rho activity in many cell types; however, the interaction between TGF $\beta$, RhoA, and its effector kinase Rho-associated protein kinase (ROCK), at tight junctions is most significant in the process of metastasis. Signaling between TGF $\beta$ and TGF $\beta$ RII results in recruitment of the E3 ubiquitin ligase Smurf1 and subsequent RhoA ubiquination and degradation at tight junctions $(13,59,60)$. These observations are supported by a study utilizing a model of metastatic breast cancer, revealing a distinct role for TGF $\beta$ mediated Par6 signaling in promoting loss of cellular polarity and morphologic transformation in mammary cells (60). Furthermore, ROCK inhibition resulted in an increased number of cells permitted to migrate through the BBB, promoting the formation of cerebral metastatic lesions (61).

\section{Cancer Stem Cells, EMT and Cerebral Metastasis}

A critical role for CSCs in cancer recurrence, maintenance and metastasis has become evident. Much like normal adult stem cells, the CSC is endowed with the capacity to selfrenew and differentiate (62). Furthermore, normal stem cells are active in two phases; cycling or quiescent; and, as such, CSCs may function in the same manner, potentially explaining the dormancy phase of a tumor, prior to the development of a metastatic lesion. Similar to embryonic stem cells, the CSCs require a specific niche provided by the microenvironment consisting of components needed to maintain stemness and differentiation (63). CSCs may contribute to tumor metastasis by the process of EMT, in which TGF $\beta$ mediated pathways generate cells with stemlike properties $(9,64)$.

Aberrant signaling of the Notch, Hedgehog and Wnt/ $\beta$ catenin pathways are crucial in the maintenance and activity of CSCs, as well as the process of EMT $(13,62)$. The critical role of Notch signaling in embryogenesis and development, 
particularly in cellular patterning and allocation of cell types to tissues strengthens the notion of its role in control of CSCs (63). Following binding of a Notch receptor to its specific ligands (i.e. Delta or Jagged), a cleaved intracellular domain translocates to the nucleus, activating transcription factors and promoting transcription of downstream target genes, such as Hes and Hey $(65,66)$. Signaling crosstalk between the Notch and components of the EMT pathway (TGF $\beta$, Snail, Slug and ZEB) has been shown to contribute to tumor progression (66-68). In fact, TGF $\beta$-mediated EMT was abrogated by knockdown of Hey1 and Jagged 1 or inactivation of Notch (69). Furthermore, Notch also induces EMT by stabilizing Snail under hypoxic conditions, via recruitment of hypoxia-inducible factor (HIF) 1a and HIF2a (70-71). In addition, elevated levels of Notch 1-3 and Jagged1 were found to be associated with disease progression and serve as markers for poor prognosis and metastasis in a model of NSCLC (72). Constitutively active Notch1 in colorectal carcinoma cell lines has been associated with an increase in EMT and stemness-related proteins such as Slug, Smad3, Jagged1, and CD44 (73). The role of the Notch pathway in brain metastasis was initially described using an animal model of breast cancer, where cerebral metastases were associated with activation of Notch1 components, along with nuclear localization of Hey 1 and Hes1 (74). Moreover, inhibition of Notch significantly reduces the incidence of brain metastases, particularly by altering the $\mathrm{CD} 44^{+} / \mathrm{CD} 24^{-}$sub-population (75). Importantly, recent evidence suggests that jagged 1 and Notch signaling is involved in establishing and promoting brain metastases from breast cancer, in a process mediated by interleukin $1 \mathrm{~b}$ in astrocytes (63).

The Wnt/ $\beta$-catenin signaling pathway appears to play a crucial role in regulation of stem cells and progression of many cancers including colon, breast and cutaneous malignancies (76-79). It is worth mentioning that Wnt also plays an important role in normal brain development, therefore activity of this pathway in metastases may suggest emulation, providing further evidence for the "seed and soil" hypothesis, as suggested by Fidler (80). The clinical significance of the canonical $\beta$-catenin-dependent pathway pertains to its involvement in cellular proliferation, differentiation and survival as well as in stem cell maintenance and reprogramming $(81,82)$. In addition, the Wnt signaling pathway regulates TGF $\beta$-mediated EMT through its interaction with E-cadherin repressors including Snail, TWIST and ZEB $(83,84)$. E-cadherin normally exists in a complex with $\beta$-catenin at the cell membrane. Therefore, loss of E-cadherin during EMT allows $\beta$-catenin to translocate to the nucleus in order to stimulate transcription of regulatory genes involved in cellular proliferation and differentiation $(82,85)$. Further crosstalk between the Wnt and TGF $\beta$ signaling pathways is evidenced by the close interaction of Smad and transcription factors induced by the Wnt pathway $(86,87)$. In a model of lung cancer, increased levels of dishevelled-3 mRNA in pleural effusions, suggesting this as a possible marker for micrometastases (88). Expression of dishevelled-1 and dishevelled-3 has been found to be increased in lung-derived brain metastases as well (89). A recent study of triple-negative breast cancer provided evidence of up-regulated Wnt pathway activity, identifying this as a marker of poor prognosis and metastatic disease, particularly to the lung and brain (90). Furthermore, up-regulation of $\mathrm{Wnt} / \beta$-catenin activity in brain metastases from basal-type breast carcinoma have been documented, as evidenced by gene expression analysis (91). On the other hand, down-regulation of $\mathrm{Wnt} / \beta$-catenin signaling in the luminal B subtype of breast cancer prevents metastasis to the brain, strengthening its role in this process (91). Therefore, targeting this pathway may prove effective in inhibiting the development of brain metastases. In fact, monoclonal antibodies against Wnt ligands and associated receptors are currently being tested for their ability to inhibit tumor growth, though most trials are still in early stages (32).

The sonic hedgehog ( $\mathrm{SHH})$ pathway is known to be a critical regulator of embryogenesis, body patterning and cancer progression (92). In the presence of SHH, smoothened proteins are released and phosphorylated to promote the activation of glioma-associated oncogene homologs (GLIs), which subsequently regulate the expression of a multitude of target genes $(93,94)$. The interaction of SHH, Wnt and TGF $\beta$ pathways is involved in regulation of the process of EMT. For example, in fibroblasts and keratinocytes, up-regulation of TGF $\beta$ signaling revealed Smad3-dependent activation of GLI1 and GLI2 (95). Activated GLI2 was associated with loss of E-cadherin and the potential to form bone metastases in a melanoma model (96). In vitro studies of the $\mathrm{SHH}$ pathway and EMT have revealed GLI1-mediated suppression of E-cadherin expression via induction of Snail (97). Studies have shown the SHH/GLI pathway to be a critical regulator of EMT, facilitating recurrence and metastasis, as well as chemotherapy resistance in models of squamous cell lung carcinoma and NSCLC (98-100). While there is limited evidence for the involvement of $\mathrm{SHH}$ in promoting brain metastases, a study conducted using samples of six metastatic brain tumors demonstrated increased expression of downstream mediators of the $\mathrm{SHH}$ pathway, particularly GLI1, which correlated positively with expression of Snail, and negatively with expression of E-cadherin, suggesting a role for EMT in brain metastases (101).

\section{Role of Micro RNA in Cerebral Metastasis}

miRNAs are small, non-coding, single-stranded RNAs that regulate gene expression by targeting mRNA transcripts, leading to their translational repression or degradation (102). 
A single miRNA can simultaneously regulate multiple genes, resulting in complex functional outcomes (103). The identification of groups of genes targeted by the same miRNA provides insight into the cross-talk between multiple signaling networks and their role in controlling diverse biological processes. Numerous miRNAs are now being identified for their role as oncogenes or tumor suppressors (104). Furthermore, extensive research has provided evidence that several microRNA are involved in the process of EMT; many of these having a role in mediating cell-cell adhesion, cytoskeletal arrangement or oncogene expression (102, 103, 105). Recently, much of the work regarding miRNA in EMT regulation focuses on the miR-200 family, which includes miR-200a, miR-200b, miR-220c, miR-141, and miR-429 (105). This association was realized upon the finding that the cells undergoing EMT in response to TGF $\beta$ had noticeably reduced miR-200 expression (15). Specifically, members of the miR-200 family were found to exert a negative regulation on ZEB1 and SIP1 expression, suggesting that down-regulation of these miRNA is required for initiation of EMT (15). This observation was further supported by the fact that members of the miR-200 family repress EMT by silencing ZEB1 and ZEB2 in gastric and breast cancer (106-108). In addition, miR-429 expression has been associated with down-regulation of mesenchymal markers including MMP2, Snail and ZEB2 (109). Interestingly, induced expression of miR-200 correlated with increased levels of E-cadherin mRNA, indicative of the reversal process of EMT, MET (15). In metastatic NSCLC cells, the expression of miR-200 correlated with reduced gene expression, particularly related to genes involved in cell signaling, invasion and proliferation (110).

Recently, miRNA expression has become a topic of interest as it pertains to mediating pathways involved in tumorgenicity as well as CSC differentiation, self-renewal and maintenance (111). Of interest, miR-107, miR153, miR204 and miR-218 are shown to influence the self-renewal and maintenance of glioma stem-like cells (112-115). In a model of breast cancer, Lin28-mediated repression of let-7 was associated with CSC production (116). Expression of miR-7 in metastatic breast CSCs was correlated with increased expression of the pluripotency gene KLF4, suggesting an important role for miRNA in CSC stemness and metastasis (117). In concordance with these studies, a pivotal role for microRNA in CSC maintenance has also been reported in models of colorectal, lung and hepatocellular carcinoma (118121). Moreover, a recent review provided evidence for a 30 miRNA signature correlating with expression in the TGF $\beta$, Notch and Wnt signaling pathways, implicating their role in regulating EMT and CSCs (103).

Recently, groups of miRNA have been identified as unique markers for metastatic tumors, suggesting a role for miRNA in developing organ-specific metastases. Importantly, a recent study using expression-based profiling of miRNA was able to accurately identify the primary tumor of origin of brain metastases in $84 \%$ of samples, suggesting an important role in diagnosis (122). Also, a group of miRNAs were described that are exclusively expressed in metastatic tumors based on the analysis of 336 cancer samples from 22 unique sites, suggesting a role in site specific metastasis (123).

While the precise mechanism by which the cerebral microenvironment interacts with tumor cells has yet to be understood, studies suggest a possible interaction between the astrocytic milieu and tumor cells, in which complex alterations of miRNA expression could take place (124). In support of this theory, a recent study demonstrated the ability of astrocytes to alter the microRNA expression patterns of lung cancer cells when co-cultured together (125). Specifically, co-cultured cells exhibited reduced expression of miR-768-3p, which was linked to increased cell viability via increases in K-ras (125). Additionally, a study of breast and bone metastatic models revealed down-regulated miR-7 expression in CSC derived from metastatic tumors, as well as an inverse relationship between miR-7 and the pluripotency gene KLF4 (117). Interestingly, this inverse relationship between miR-7 and KLF4 was also associated with metastasis-free survival only in brain metastases, demonstrating a site-specific interaction between microRNA, CSCs and the cerebral microenvironment, leading to prognostic implications. Global patterns of gene expression demonstrated an up-regulation of hsa-miR-17-5p in triplenegative breast cancer tissues in The Cancer Genome Atlas (TCGA). In addition, a negative correlation between hsamiR-17-5p and overall survival as well as PTEN and BCL2 target genes was observed in TCGA breast cancer specimens (126). Other miRNAs were found to have roles in tumor cell invasion and extravasation through the BBB. Specifically, miR-1258 was shown to regulate expression of heparanase, a pro-metastatic enzyme stored in endothelial and glial cells, involved in breakdown of heparan-sulfate chains, rendering cells more capable of crossing the $\operatorname{BBB}(127,128)$. In addition, miR-22 and miR-378 mediate expression of MMP2, MMP-9 and VEGF, implicating a cross-talk between the tumor cells, extracellular matrix and vasculature in facilitating invasion and establishing secondary lesions in the brain. Interestingly, aberrant expression of miR-10b, miR29c, miR-145, miR-146a, miR-200, miR-210, miR-199a/b and $\mathrm{miR}-768-3 \mathrm{p}$ were discovered in cerebral metastatic lesions from multiple primary tumors, suggesting the pivotal role of miRNA in brain metastasis, which has potential to aid in diagnosis, prognosis and discovery of therapeutic targets.

Involvement of approximately 38 distinct miRNA associated with cerebral metastases from different primary tumors (NSCLC, breast, CRC, melanoma and renal tumors) are presented in Table I (129-165). Of these miRNA, 25 were found to have increased expression, 10 were found to 
have decreased expression, and 3 were found to have variable expression, when compared to their matched primary tumor counterparts (Table I).

\section{Genetics Associated with Cerebral Metastasis}

Studies of gene expression have suggested the existence of a genetic signature present in primary tumors that defines their metastatic potential (166). While, much debate has since emerged regarding the significance of genetic signatures and their role in metastasis, Fidler and colleagues suggested that the process of metastasis requires cancer cells to acquire additional mutations in order to develop metastatic potential (167). Furthermore, it has been demonstrated that while a genetic signature for poor prognosis may exist, an additional set of genetic aberrations contributes to the sitespecific dissemination of metastatic tumor cells (168). Rather than directing the process of metastasis, this study suggests that the genes corresponding to poor prognosis may instead provide tumor cells with baseline metastatic properties with a phenotype encouraging metastasis (168). Alternatively, a model of breast-derived brain metastases suggests that it is not a genetic signature that predetermines a tumors clinical course, but rather a unique interaction between the tumor and its microenvironment that contributes to disease progression (80). Given the significance of genetic markers in defining tumor progression and metastasis, it is prudent to detail genetic markers as they pertain to cerebral dissemination from the breast, lung, skin, colon and kidney (See Figure 1 for details).

\section{Breast}

Approximately $10-30 \%$ of breast cancer patients will develop cerebral metastases (169). In patients with metastatic breast cancer brain metastases were shown to have the worst prognosis ( 7.35 months), followed by metastases to the liver (36.7 months), bone (44.4 months) and lung (58.5 months). Brain metastases from breast cancer can be stratified based on hormone receptor status. About $25 \%$ of patients with breast cancer have an amplification in HER2 and, of these, $30-55 \%$ develop metastatic brain lesions (170-174). This risk is elevated in the setting of hormone-receptor negativity $(175,176)$. Median survival of patients with HER2-positive, ER-negative brain metastases has been found to be approximately 28 months (177). A study of 66 patients with HER2 breast cancer displayed good performance status, controlled extracranial disease and single brain metastases had better outcome (178). Patients with triple-negative breast cancer $\left(\mathrm{ER}^{-} / \mathrm{PR}^{-} / \mathrm{HER} 2^{-}\right)$, on the other hand, are at increased risk of first recurrence of cerebral metastasis (179) with a tendency to cluster early in the patient's disease trajectory (175). These patients are at a $25-46 \%$ risk of developing
CNS metastasis (180-182) with a survival time of less than six months $(179,182,183)$.

In a model of breast cancer, gene expression analysis revealed 243 genes that were differentially expressed in metastatic cell lines, of those, 17 genes were highly correlated with brain metastasis (184). More importantly, these genes did not coincide with those involved in metastasis to other organs. Among the 17 genes, COX2, EGFR ligand HBEGF and the a2,6-sialyltransferase ST6GALNAC5 were identified as mediators of homing, cancer cell migration and passage through the BBB. Findings also indicate that in breast cancer, a long period of remission often precedes distant relapse, supporting the notion that breast cancer cells initially lack the full competence for outgrowth in distant organs but develop this under the selective pressure of different organ microenvironments $(168,184-186)$. Alternatively, a recent study of 18 primary and 42 breast cancer-derived brain metastases found mutations in the TP53, PIK3CA, KIT, $M L H 1$ and $R B 1$ genes, within which no mutations were found to be unique to cerebral metastases (187). Interestingly, in a matched pair of primary tumor and metastatic brain lesion, a mutation in p53 was discovered, however the acquisition of additional mutations might have occurred during the metastatic process (187). Mutations in TP53 were also found with a higher frequency in metastatic tumors, compared to primary breast cancer cells $(187,188)$. A similar study, using expression profiling of 23 matched sets of brain metastases and primary breast tumors, found DNA double-strand break repair genes $B A R D 1$ and $R A D 51$ to be up-regulated in samples of metastatic lesions, suggesting a role for these genes in evading the effects of reactive oxygen species in the brain (189). Studies of epigenetic gene regulation have revealed differential methylation patterns of genes exist between brain metastases and their primary tumor counterparts $(190,191)$. Importantly, one study found the $B N C l$ gene to be more frequently methylated in metastatic tumors than in primary breast cancer (190). BNC1 is a target of TGF $\beta$ in mediating EMT, as its expression is preserved in primary breast tumors while silent in metastatic lesions (191). This suggests its initial role in promotion of EMT, thereafter possibly contributing to MET while establishing secondary lesions (190).

\section{Lung}

The pathogenesis of lung cancer exists in two broad clinical subtypes, namely non-small cell carcinoma (NSCLC), representing approximately $75-85 \%$ of tumors, and small cell lung carcinoma (SCLC) accounting for the remaining $15-25 \%$. Of these, approximately $30-50 \%$ are likely to develop cerebral metastases; where $25 \%$ arise from NSCLC (192, 193). The development of cerebral metastases is considered an indicator of advanced disease and poor 
Table I. microRNAs involvement in brain metastasis.

\begin{tabular}{|c|c|c|c|c|}
\hline miRNA & Primary site & $\begin{array}{l}\text { Pattern of } \\
\text { expression }\end{array}$ & Proposed role in metastasis & Reference \\
\hline $\operatorname{miR}-1$ & $\mathrm{CRC}$ & $\uparrow$ & Interaction with MACC1 & 129,130 \\
\hline $\operatorname{miR}-7$ & $\mathrm{BC}$ & $\downarrow$ & Increased KLF4 expression & 117 \\
\hline miR-9 & $\mathrm{BC} ; \mathrm{CRC}$ & $\uparrow$ & Inhibition of E-cadherin & 131,132 \\
\hline $\operatorname{miR}-10 b$ & $\mathrm{BC} ; \mathrm{CRC} ; \mathrm{ccRCC}$ & $\begin{array}{c}\uparrow \mathrm{BC} \\
\uparrow \mathrm{CRC} \\
\downarrow \mathrm{ccRCC}\end{array}$ & $\begin{array}{c}\text { Modulation of HOXD10, TIAM1, MICB, TIP30, 129, 133, } 134 \\
\text { Twist and E-cadherin expression }\end{array}$ & \\
\hline $\operatorname{miR}-15 b$ & Melanoma & $\uparrow$ & & 135 \\
\hline miR-16 & Melanoma & $\uparrow$ & Inhibition of EMT via phosphorylation of FAK and Akt proteins & 135,136 \\
\hline miR-19a & $\mathrm{BC}$ & $\downarrow$ & Regulation of cyclin D1, Bim, TNFa and PTEN expression & 137,138 \\
\hline $\operatorname{miR}-20 b$ & $\mathrm{BC}$ & $\uparrow$ & Suppression of PTEN & 139,140 \\
\hline $\operatorname{miR}-21$ & NSCLC & $\uparrow$ & Downstream mediator of STAT3 & 141 \\
\hline $\operatorname{miR}-22$ & $\mathrm{CRC}$ & $\uparrow$ & Modulation of TIAM1, MMP-2, MMP-9 and VEGF expression & 129,142 \\
\hline $\operatorname{miR}-28$ & $\mathrm{CRC}$ & $\uparrow$ & Targeting of CCND1 and HOXB3 expression & 129,143 \\
\hline $\operatorname{miR}-29 \mathrm{c}$ & $\begin{array}{l}\mathrm{BC} ; \\
\text { Melanoma }\end{array}$ & $\begin{array}{c}\downarrow \text { BC } \\
\downarrow \text { Melanoma }\end{array}$ & $\begin{array}{l}\text { Epigenetic regulation of tumor-related genes; } \\
\text { Targeting of TIMP3, PDCD4 and RASA1 }\end{array}$ & $137,144,145$ \\
\hline $\operatorname{miR}-31$ & CRC & $\downarrow$ & Downstream effector of TGFb that targets TIAM1 & 129,146 \\
\hline mIR-95 & NSCLC & $\downarrow$ & Suppression of cyclin D1 & 147 \\
\hline $\operatorname{miR}-125 b$ & $\mathrm{CRC}$ & $\uparrow$ & Suppression of LIN28B & 129 \\
\hline $\operatorname{miR}-126$ & $\mathrm{CRC}$ & $\uparrow$ & Inhibition of the RhoA/ROCK signaling & 129,148 \\
\hline $\mathrm{miR}-133 \mathrm{a} / \mathrm{b}$ & $\mathrm{CRC}$ & $\uparrow$ & $\begin{array}{c}\text { Downstream target of TPp63 with inhibitory effect on RhoA, } \\
\text { E-cadherin and vimentin }\end{array}$ & 129,149 \\
\hline $\operatorname{miR}-143$ & $\mathrm{CRC}$ & $\uparrow$ & Regulation of MACC1 expression & 121,129 \\
\hline $\operatorname{miR}-145$ & NSCLC; CRC & $\begin{array}{c}\uparrow \mathrm{NSCLC} \\
\downarrow \mathrm{CRC}\end{array}$ & Targeting of OCT4, EGFR, c-myc, MUC1, TPD52 and NUDT1 & $129,150,151$ \\
\hline miR-146a & $\mathrm{BC} ; \mathrm{CRC}$ & $\begin{array}{l}\downarrow \mathrm{BC} \\
\uparrow \mathrm{CRC}\end{array}$ & Modulation of b-catenin and hnRNPC expression & 129,152 \\
\hline $\operatorname{miR}-150$ & Melanoma & $\uparrow$ & Targeting of $\mathrm{c}-\mathrm{Myb}$ & 135,153 \\
\hline miR-184 & NSCLC & $\uparrow$ & Inhibitor of c-myc and CCND1; induction of p15 and p21 & 154,155 \\
\hline $\operatorname{miR}-197$ & NSCLC & $\uparrow$ & Negative regulator of FUS1 & 154,156 \\
\hline $\operatorname{miR}-199 \mathrm{a} / \mathrm{b}$ & $\mathrm{CRC} ; \mathrm{ccRCC}$ & $\begin{array}{l}\uparrow \mathrm{CRC} \\
\uparrow \mathrm{ccRCC}\end{array}$ & Regulation of HES1; inhibition of c-Met & $\begin{array}{l}129,134 \\
157,158\end{array}$ \\
\hline $\operatorname{miR}-200$ & BC; Lung & $\begin{array}{l}\uparrow \mathrm{BC} \\
\uparrow \text { Lung }\end{array}$ & Targeting of ZEB1 and ZEB2 & 159 \\
\hline $\operatorname{miR}-210$ & BC; Melanoma & $\begin{array}{c}\uparrow \mathrm{BC} \\
\uparrow \text { Melanoma }\end{array}$ & Targeting of MNT; Induction of angiogenesis after hypoxia & $137,160,161$ \\
\hline $\operatorname{miR}-328$ & NSCLC & $\uparrow$ & Up-regulation of PRKCA & 162 \\
\hline miR-374 & Melanoma & $\uparrow$ & & 135 \\
\hline $\operatorname{miR}-378$ & NSCLC & $\uparrow$ & Up-regulation of MMP-2, MMP-9 and VEGF & 163 \\
\hline miR-509 & $\mathrm{BC}$ & $\downarrow$ & Suppression of RhoC and TNFa & 164 \\
\hline $\operatorname{miR}-542$ & Melanoma & $\downarrow$ & Down-regulation of PIM1 & 165 \\
\hline miR-576 & CRC & $\uparrow$ & & 129 \\
\hline miR-768-3p & BC; Lung & $\begin{array}{l}\downarrow \text { BC } \\
\downarrow \text { Lung }\end{array}$ & Targeting K-ras & 125 \\
\hline $\operatorname{miR}-1258$ & $\mathrm{BC}$ & $\downarrow$ & Inhibition of heparanase & 127 \\
\hline HS_170 & $\mathrm{CRC}$ & $\downarrow$ & & 129 \\
\hline HS_287 & $\mathrm{CRC}$ & $\uparrow$ & & 129 \\
\hline
\end{tabular}

prognosis. Without treatment, median survival time ranges from only 1-2 months, expanding to 4-6 months with the addition of radiotherapy (193-195). Improved survival in patients with single brain metastases derived from NSCLC has been shown with the addition of neurosurgical resection and/or radiosurgery with mean survival times approaching 12-14 months (193).
A study comparing expression data between 16 metastatic brain tumors with 37 primary NSCLC samples revealed 244 genes with altered expression levels, corresponding to genes involved in adhesion, cell-cell communication and motility (196). A similar study, comparing brain metastases from NSCLC to non-metastatic lung tissue assessed 17,000 genes and found 1,561 to have altered expression, showing genes involved 


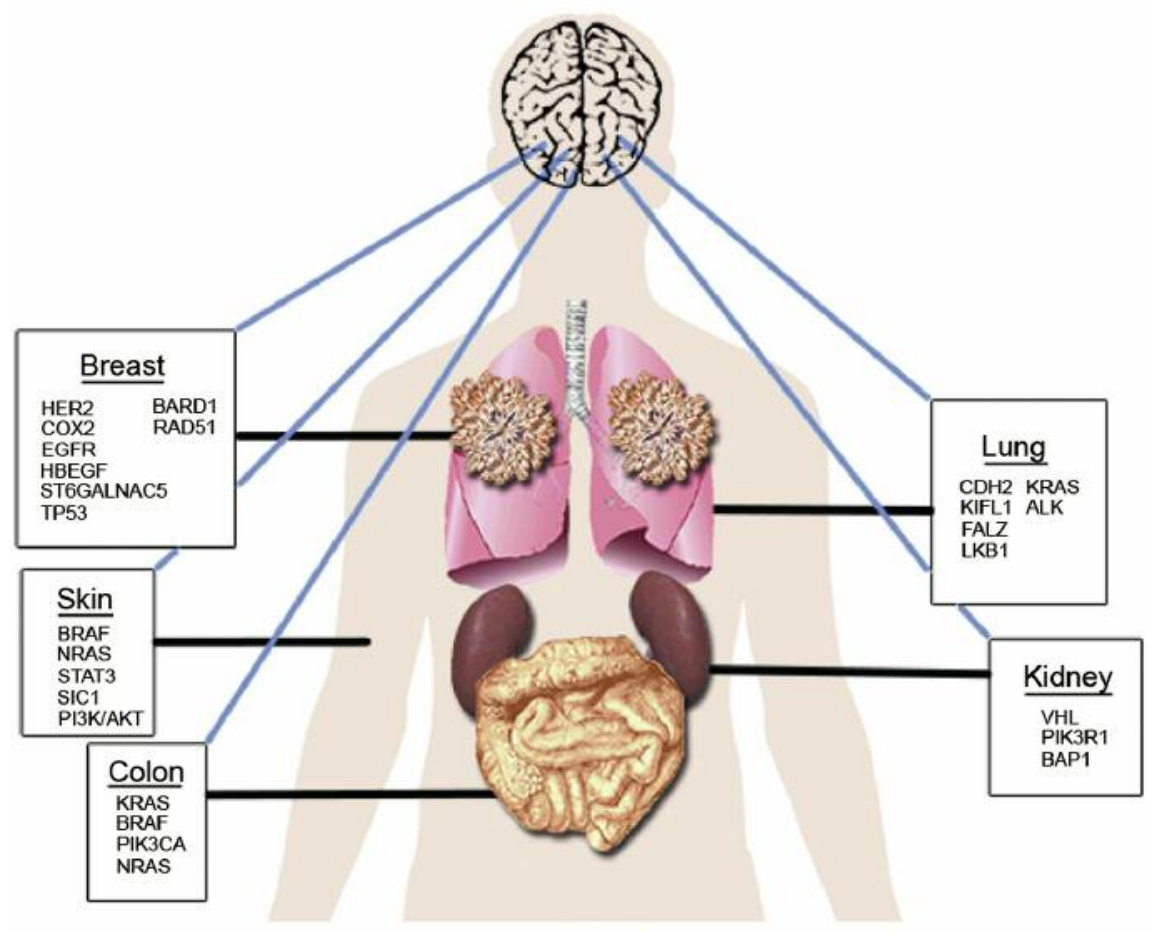

Figure 1. Genes associated with cerebral metastasis from distinct organ sites. Figure represents the alterations in unambiguous genes linked with brain metastasis from breast, lung, kidney, colon or skin.

in adhesion, motility and angiogenesis to be up-regulated, and genes involved in apoptosis and neuroprotection to be downregulated (197). Furthermore, analysis of 12 candidate genes from samples of NSCLC, assessing the correlation between gene expression and occurrence of brain metastases found three genes, CDH2, KIFL1 and FALZ, to be predictive of brain metastases (4). Importantly, $\mathrm{CDH} 2$ is known to regulate adhesion, and is a mediator of EMT, suggesting its role in this process $(4,198,199)$. Similarly, loss of LKB1 and mutation of KRAS have been shown to be predictive of brain metastases in NSCLC (200). Recent genomic analysis using comparative genome hybridization techniques has revealed numerous copy number variations $(\mathrm{CNV})$ predictive of brain metastases from primary NSCLC $(201,202)$. An increase in the number of CNVs has been observed in secondary tumors in comparison to their primary counterpart, suggesting a degree of genetic variability that takes place during the metastatic process (201).

A recent study has demonstrated that about $21.9 \%$ patients with NSCLC showed the expression of programmed cell death-ligand 1 (PD-L1) in brain metastases. Furthermore, PD-L1 positivity in brain metastasis samples was seen in patients with heavy smoking history as well as radiotherapeutic treatments giver prior to surgery (203).

Interestingly, a newly discovered rearrangement of anaplastic lymphoma kinase (ALK) is seen in about 2-7\% of
NSCLC (204) and has recently become a marker of interest for targeted chemotherapy. The propensity for ALK-rearranged NSCLC to metastasize to the brain has been a subject of contention, with several studies citing greater likelihood (205), however others show no significant increase in brain metastases (206). Crizotinib, a first-generation ALK inhibitor, is shown to be highly efficacious against ALK-positive NSCLC and is currently approved for first-line treatment $(207,208)$, however it is important to consider that CNS progression develops in up to $60 \%$ of patients treated with this chemotherapeutic agent (204). The pattern of CNS progression in patients receiving crizotinib was studied by Costa et al., who discovered poor CSF concentrations of the drug, due, in part, to both passive diffusion restriction and active efflux via $\mathrm{P}$ glycoprotein $(209,210)$. Several second generation ALKinhibitors, such as alectinib, ceritinib, and brigatinib, are currently in clinical trials, with positive results due to better CNS penetrance, however, ongoing preclinical studies are awaiting outcome (211-213). Perhaps the novel of ALKinhibitors is the third-generation, loratinib, believed to be effective against all resistant mutants of ALK+ NSCLC (214, 215). Clinical trials for this novel chemotherapeutic agent are currently underway, with published evidence from one patient indicating a favorable treatment response and re-sensitization to crizotinib $(211,214)$. 


\section{Skin}

Brain metastasis is common in association with melanoma, occurring in up to $75 \%$ of patients with stage IV disease (216). Greater than $50 \%$ of melanoma-related deaths are a result of brain metastases, with the median survival for these patients determined to be approximately 3 to 6 months $(217,218)$. Interestingly, while lung, breast and melanoma cancers are the most common sources of cerebral metastases; melanoma is by far the least prevalent in the general population, reflecting its heightened propensity to metastasize to the brain (216).

Comparisons of metastatic melanoma to non-metastatic primary cutaneous malignancies have revealed many genetic variations, as confirmed by expression array analysis (219). With respect to melanoma, the BRAF gene is crucial in the development of disease, while members of the MAPK-ERK pathway, including MEK1/2 and ERK1/2 components, are also involved in progression of disease $(220,221)$. There are a number of somatic mutations, including an activating mutation in the BRAF gene, which lead to subsequent activation of the MAPK pathway in melanomas that are thought to promote tumorigenic progression and subsequent invasion of cells with malignant potential (222). Interestingly, a study of paired primary melanomas with metastases from the same patients revealed BRAF/NRAS mutations of similar frequency in both sets of samples, suggesting that BRAF confers metastatic potential, however does not confer organ-specificity (223). Studies have shown that the $B R A F^{\mathrm{V} 600 \mathrm{~K}}$ mutation is associated with higher cerebral $(75 \%$ vs. $36.3 \%)$ and lung (91.6\% vs. $47.7 \%)$ metastases, relative to other BRAF mutations (224). Furthermore, patients with $B R A F^{\mathrm{V} 600 \mathrm{~K}}$ mutations were found to have a shorter latency to metastasis and overall survival, suggesting this mutation to be a potential therapeutic target (224). Ipilimumab, a monoclonal antibody against cytotoxic T-lymphocyte-associtated antigen 4 (CTLA4), and specific inhibitors of mutated $B R A F^{\mathrm{V} 600 \mathrm{E}}$ protein, such as dabrafenib and vemurafenib, are newer therapies approved for treating metastatic melanoma. These therapeutics, however, have poor efficacy in attenuating cerebral metastases (225).

Recent studies have identified signaling molecules PSTAT3, SOC1 and PI3K/AKT to be activated in melanomaderived brain metastases and have a significant difference from extra-cranial metastases $(34,226,227)$. Molecular analysis of matched pairs of melanoma-derived brain and extra-cranial metastases revealed enhanced activation of PI3K/AKT pathway in patients with brain metastases (216). The activation of the PI3K/AKT pathway is governed by multiple upstream signaling components and, as such, it is possible that an interaction between the tumor cells and cerebral microenvironment exists and contributes to progression of disease (216). Interestingly, activation of the $\mathrm{PI} 3 \mathrm{~K} / \mathrm{AKT}$ pathway is often correlated with treatment resistance in BRAF-mutant cell lines, implying that combined inhibition of both the PI3K/AKT and MAPK pathways in melanoma may be necessary to reduce tumor burden and disease progression (216).

\section{Colon}

Colorectal carcinoma (CRC) is one of the most commonly diagnosed cancers worldwide, and despite total resection of the primary lesion; distant metastases have been reported to occur in up to $15 \%$ of patients $(228,229)$. The incidence of brain metastases in patients with CRC is between $0.3-6 \%$ (3, $230,231)$. Interestingly, the brain is the sole organ of metastatic disease in up to $10 \%$ of patients with metastatic CRC $(229,232,233)$. While cerebral metastatic disease is more uncommon than perhaps the liver or lung, it remains a primary focus as the course is far more fatal, with median survival times reported between 3-6 months (229, 234-236).

Recent advances in genomic analyses have revealed abnormalities in several genes, namely KRAS, BRAF, PIK3CA and NRAS, which may play a role in patterns of metastatic CRC. A study of advanced cancers possessing the mutant BRAF gene revealed that patients with CRC exhibited a trend towards a shorter interval to metastasis, albeit this relationship failed to reach statistical significance due to the small number of patients (224). Consistent with this, another study showed trend level data linking BRAF mutations to the development of brain metastases in colorectal cancer (237). As seen in studies of metastatic melanoma, one CRC patient with cerebral metastases exhibited the V600K variant of the BRAF mutation (224). Interestingly, the BRAF mutation, found in up to $15 \%$ of metastatic CRC, is associated with induction of EMT and the development of lymph node metastases (238). These finding suggest an important functional mechanism governed by mutations in BRAF for the progression of $\mathrm{CRC}$ and overall risk of developing metastatic disease (239). KRAS mutations are the most common genetic aberrations associated with CRC, occurring in up to $50 \%$ of colorectal malignancies (239). While there has been no evidence to suggest the presence of a specific mechanism linking KRAS mutations to the development of cerebral metastases, a recent study has shown an increased prevalence of KRAS mutations in CRC-derived brain and lung metastases, relative to liver metastases (240). Furthermore, an association between KRAS mutations and increased recurrence of brain metastases is seen in up to $14.5 \%$, as compared to only $2 \%$ in wild-type populations (241). Although the KRAS mutation is considered a driver event in CRC, the mechanism of its involvement in metastasis remains to be elucidated. Interestingly, another genetic aberration in the PIK3CA gene, which encodes a catalytic isoform of the phosphatidylinositol 3-kinase (PI3K) presents in up to $20 \%$ of CRC (239). Up to $1.4 \%$ of patients 
with CRC-derived brain metastases display a mutation in the PIK3CA gene (242). It is important to note that up to $70 \%$ of patients harboring this mutation, concurrently possess mutations in KRAS, which may exert a strong contribution to the formation of cerebral metastases (239).

\section{Kidney}

Despite many advances in defining the molecular mechanisms by which cancers disseminate and form cerebral metastases, those underlying the progression metastasis of renal cell carcinoma (RCC) remain unclear. Mutations in the von Hippel Lindau (VHL) gene and aberrations in mTOR pathway activity have been established as mediators of cell growth and disease progression in RCC (243). Evidence from expression analysis comparing matched samples from primary and adrenal metastases of RCC revealed 166 differentially expressed genes, which included several genes related to cell adhesion and extracellular matrix proteins (244). Importantly, metastatic samples exhibited upregulation of TGF $\beta$-related genes, as well as markers of mesenchymal cell types, suggesting a role for EMT and MET in the metastatic process in RCC (244). Recent studies have also shown that a high degree of intratumoral heterogeneity within primary renal cell carcinoma contributes to evasion of available therapeutics, which allows for rapid progression of disease $(245,246)$. Interestingly, while RCC appears to be a heterogeneous tumor, a recent study demonstrated that brain metastases derived from RCC appear to be monoclonal in origin, implying a discrete cell population had metastatic potential with a propensity to disseminate to the brain (246). Additionally, a non-sense mutation in the PIK3R1 gene, encoding the inhibitory subunit of PI3K, was identified as a specific mutation unique to RCC-derived brain metastases (246). Loss of BRCAAssociated Protein 1 (BAP1), a deubiquitinating enzyme, has also been implicated as a marker of poor prognosis and aggressive behavior in RCC, representing a potential target for new therapeutics $(243,247)$. While these studies have shed light on the mechanisms that may be responsible for cerebral metastasis in RCC, additional studies are needed to characterize the genetic contribution to cerebral dissemination, especially given the propensity for these tumors to metastasize to the brain.

\section{Conclusion}

Brain metastases are a leading cause of morbidity and mortality among cancer patients, and are reported to occur in about $40 \%$ of cancer patients in the United States $(1,2)$. In general, the median survival following a diagnosis of cerebral metastases is between 2 and 25 months, depending on the origin of the primary tumor and time of diagnosis (5,
6). Most brain metastases are typically associated with peritumoral edema. A correlation of tumor and edema volumes with overall survival in patients with cerebral metastases showed that the extent of edema surrounding cerebral metastases is not linked to effect overall survival in patients with brain metastases (248). Given that metastasis is the driving force behind morbidity and mortality for most patients, it is essential to identify the characteristics of these aberrant cancer cells that allow them to spread to distant sites in the body and develop into metastatic tumors.

Primary tumors are thought to be comprised of multiple subpopulations of cells having the capacity to metastasize through activation of multiple interrelated signaling pathways and a complex interaction between the primary cell, host cellular environment (platelets, endothelium, leukocytes and astrocytes) and effector molecules. Specifically, TGF $\beta$-mediated EMT and its reversal process MET play critical roles in the control of many aspects of cancer progression by allowing epithelial cells the capacity to extravasate into the peripheral circulation, migrate and colonize in the cerebral microenvironment. The progression of tumor cells through a CSC-like state provides a crucial link in facilitating the transition between cell phenotypes and offers insight into the mechanisms underlying chemotherapy resistance and tumor re-growth in metastatic cancers. Furthermore, the discovery that miRNAs play a significant role in the regulation of multiple genes related to both the processes of EMT and CSC maintenance provides another layer of evidence for the complex interaction between epigenetic regulation and the molecular pathways responsible for metastasis, as well as potential therapeutic targets for intervention.

With improved local control and management of primary tumors, the incidence of late diagnosed brain metastases as well as their associated morbidity and mortality remains an unmet concern (80). While the mechanisms described above provide insight into a host of potential therapeutic targets, the development of an effective and innocuous agent remains a considerable challenge. In recent years, the discovery of genetic aberrations associated with brain metastases has provided a fundamental contribution to the development of novel therapeutic agents. While much progress has been made, further characterization of these pathways and processes is necessary to allow for more efficacious therapeutic targets. The continued development of brain metastasis models and identification of molecular signatures of metastatic pathways will advance our understanding of these complex communication networks and will ultimately lead to the development of therapeutic strategies.

\section{Acknowledgements}

The Authors would like to acknowledge support of findings from Advanced Research Foundation. 


\section{References}

1 Platta CS, Khuntia D, Mehta MP and Suh JH: Current treatment strategies for brain metastasis and complications from therapeutic techniques: a review of current literature. Am J Clin Oncol 33: 398-407, 2010

2 Soffietti R, Rudā R and Mutani R: Management of brain metastases. J Neurol 249: 1357-1369, 2002.

3 Barnholtz-Sloan JS, Sloan AE, Davis FG, Vigneau FD, Lai P and Sawaya RE: Incidence proportions of brain metastases in patients diagnosed (1973 to 2001) in the Metropolitan Detroit Cancer Surveillance System. J Clin Oncol 22(14): 2865-2872, 2004.

4 Grinberg-Rashi H, Ofek E, Perelman M, Skarda J, Yarcon P, Hajduch M, Jacob-Hirsch J, Amariglio N, Krupsky M, Simansky DA, Ram Z, Pfeffer R, Galernter I, Steinberg DM, Ben-Dov I, Rechavi $G$ and Izraeli $S$ : The expression of three genes in primary non-small cell lung cancer is associated with metastatic spread to the brain. Clin Cancer Res 15: 1755-1761, 2009.

5 Lin X and DeAngelis LM: Treatment of Brain Metastases. J Clin Oncol 33: 1-10, 2015.

6 Sperduto PW, Kased N, Roberge D, Xu Z, Shanley R, Luo X, Sneed PK, Chao ST, Weil RJ, Suh J, Bhatt A, Jensen AW, Brown PD, Shih HA, Kirkpatrick J, Gaspar LE, Fiveash JB, Chiang V, Knisely JP, Sperduto CM, Lin N and Mehta M: Summary report on the graded prognostic assessment: anaccurate and facile diagnosis-specific tool to estimate survival for patients with brain metastases. J Clin Oncol 30: 419-425, 2012.

7 Kanazawa Y, Fujita I, Kakinuma D, Aoki Y, Kanno H, Arai H, Matsuno K, Shimoda T, Matsutani T, Hagiwara N, Nomura T, Yamada T, Kato S, Nairobi Z, Takasaki H and Uchita E: Fiveyear survival after surgical removal and gamma-knife stereotactic radiosurgery for a cerebellar metastasis from an esophagogastric junction cancer: A case report and literature review. In Vivo 31(6): 1209-1214, 2017.

8 Karagkiouzis G, Spartalis E, Moris D, Patsouras D, Athanasiou A, Karathanasis I, Verveniotis A, Konstantinou F, Kouerinis I, Potaris K, Dimitroulis D and Tomos P: Surgical management of non-small cell lung cancer with solitary hematogenous metastases. In Vivo 31(3): 451-454, 2017.

9 Mani SA, Guo W, Liao MJ, Eaton EN, Ayyanan A, Zhou AY, Brooks M, Reinhard G, Zhang CC, Shipitsin M, Campbell LL, Polyak K, Brisken C, Yang J and Weinberg RA: The epithelialmesenchymal transition generates cells with properties of stem cells. Cell 133: 704-715, 2008

10 Tam WL and Weinberg RA: The epigenetics of epithelialmesenchymal plasticity in cancer. Nat Med 19: 1438-1449, 2013.

11 Lagamba D, Nawshad A and Hay ED: Microarray analysis of gene expression during epithelial-mesenchymal transformation. Dev Dyn 234: 132-142, 2005.

12 Peinado H, Olmeda D and Cano A: Snail, ZEB and b HLH factors in tumour progression: an alliance against the epithelial phenotype. Nat Rev 7: 415-428, 2007.

$13 \mathrm{Xu}$ J, Lamouille S and Derynck R: TGF- $\beta$ induced epithelial to mesenchymal transition. Cell Res 19: 156-172, 2009.

14 Papageorgis P: TGF $\beta$ signaling in tumor initiation, epithelialto-mesenchymal transition, and metastasis. J Oncol 2015: 1-15, 2015.

15 Gregory PA, Bert AG, Paterson EL, Barry SC, Tsykin A, Farshid G, Vadas MA, Goodall YK and Goodall GJ: The miR-
200 family and miR-205 regulate epithelial to mesenchymal transition by targeting ZEB1 and SIP1. Nat Cell Biol 10: 593$601,2008$.

16 Moustakas A and Heldin $\mathrm{CH}$ : Induction of epithelialmesenchymal transition by transforming growth factor $b$. Seminars in Cancer Biology 22: 446-454, 2012.

17 Jeevan D, Cooper JB, Braun A, Murali R and Jhanwar-Uniyal $\mathrm{M}$ : Molecular pathways mediating metastases to the brain via epithelial-to-mesenchymal transition: genes, proteins, and functional analysis. Anticancer Research 36: 523-532, 2016.

18 Gupta $\mathrm{P}$ and Srivastava SK: HER2 mediated de novo production of TGF $\beta$ leads to SNAIL driven epithelial-tomesenchymal transition and metastasis of breast cancer. Mol Oncol 8: 1532-1547, 2014

19 Dave N, Guaita-Esteruelas S, Gutarra S, Frias A, Beltran M, Peiro $S$ and de Herreros AG: Functional cooperation between Snail 1 and TWIST in the regulation of ZEB1 expression during epithelial to mesenchymal transition. J Biol Chem 286: 1202412032, 2011

20 Nieto MA: The ins and outs of the epithelial to mesenchymal transition in health and disease. Ann Rev Cell Dev Biol 27: 347-376, 2011.

21 Yang MH, Wu MZ, Chiou SH, Chen PM, Chang SY, Liu CJ, Teng SC and Wu KJ: Direct regulation of TWIST by HIF1alpha promotes metastasis. Nat Cell Biol 10: 295-305, 2008.

22 Ansieau S, Bastid J, Doreau A, Morel AP, Bouchet BP, Thomas C, Fauvet F, Puisieux I, Doglioni C, Piccinin S, Maestro R, Voeltzel T, Selmi A, Valsesia-Wittmann S, Caron de Fromentel $\mathrm{C}$ and Puisieux A: Induction of EMT by TWIST proteins as a collateral effect of tumor-promoting inactivation of premature senescence. Cancer Cell 14: 79-89, 2008.

23 Hoek K, Rimm DL, Williams KR, Zhao H, Ariyan S, Lin A, Kluger HM, Berger AJ, Cheng E, Trombetta ES, Wu T, Niinobe M, Yoshikawa K, Hannigan GE and Halaban R: Expression profiling reveals novel pathways in the transformation of melanocytes to melanomas. Cancer Res 64: 5270-5282, 2004.

24 Martin TA, Goyal A, Watkins G and Jiang WE: Expression of the transcription factors snail, slug and TWIST and their clinical significance in human breast cancer. Ann Surg Oncol 12: 488-496, 2005.

25 Mironchik Y, Winnard PT Jr., Vesuna F, Kato Y, Wildes F, Pathak AP, Kominsky S, Artemov D, Bhujwalla Z, Van Diest $\mathrm{P}$, Burger H, Glackin C and Raman V: TWIST overexpression induces in vivo angiogenesis and correlates with chromosomal instability in breast cancer. Cancer Res 65: 10801-10809, 2005.

26 Kwok WK, Ling MT, Lee TW, Lau TC, Zhou C, Zhang X, Chua CW, Chan KW, Chan FL, Glackin C, Wong YC and Wang X: Up-regulation of TWIST in prostate cancer and its implication as a therapeutic target. Cancer Res 65: 5153-5162, 2005.

27 Yuen HF, Chan YP, Wong ML, Kwok WK, Chan KK, Lee PY, Srivastava G, Law SY, Wong YC, Wang X and Chan KW: Upregulation of TWIST in oesophageal squamous cell carcinoma is associated with neoplastic transformation and distant metastasis. J Clin Pathol 60: 510-514, 2006.

28 Lee TK, Poon RT, Yuen AP, Ling MT, Kwok WK, Wang WH, Wong YC, Guan XY, Man K, Chau KL and Fan ST: TWIST overexpression correlates with hepatocellular carcinoma metastasis through induction of epithelial-mesenchymal transition. Clin Cancer Res 12: 5369-5376, 2006. 
29 Kyo S, Sakaguchi J, Ohno S, Mizumoto Y, Maida Y, Hashimoto M, Nakamura M, Takakura M, Nakajima M, Masutomi K and Inoue M: High TWIST expression is involved in infiltrative endometrial cancer and affects patient survival. Hum Pathol 37: 431-438, 2006.

30 Haura EB, Zheng Z, Song L, Cantor A and Bepler G: Activated epidermal growth factor receptor - Stat-3 signaling promotes tumor survival in vivo in non-small cell lung cancer. Hum Cancer Biol 11: 8288-8294, 2005.

31 Lo HW, Hsu SC, Xia W, Cao X, Shih JY, Wei Y, Abbruzzese JL, Hortobagyi GN and Hung MC: Epidermal growth factor receptor cooperates with signal transducer and activator of transcription 3 to induce epithelial-mesenchymal transition in cancer cells via up-regulation of TWIST gene expression. Cancer Res 67: 9066-9076, 2007.

32 Zhang $X$ and Hao J: Development of anticancer agents targeting the Wnt/ $\beta$-catenin signaling. Am J Cancer Res 5: 2344-2360, 2015.

33 Hajimoradi M, Hassan ZM, Ebrahimi M, Soleimani M, Bakhshi M, Firouzi J and Samani FS: STAT3 is overactivated in gastric cancer stem-like cells. Cell J 17: 617-628, 2016.

34 Xie TX, Huang FJ, Aldape KD, Kang SH, Liu M, Gershenwald JE, Xie K, Sawaya R and Huang S: Activation of stat3 in human melanoma promotes brain metastasis. Cancer Res 66: 3188-3196, 2006.

35 Valcourt U, Kowanetz M, Niimi H, Heldin $\mathrm{CH}$ and Moustakas A: TGF $\beta$ and the Smad signaling pathway support transcriptomic reprogramming during epithelial-mesenchymal cell transition. Mol Biol Cell 16: 1987-2002, 2005.

36 Derynck $\mathrm{R}$ and Zhang YE: Smad-dependent and Smadindependent pathways in TGF $\beta$ family signaling. Nature 425: 577-584, 2003

37 Funaba M, Zimmerman CM and Mathews LS: Modulation of Smad2-mediated signaling by extracellular signal-regulated kinase. J Biol Chem 277: 41361-41368, 2002.

38 Lehmann K, Janda E, Pierreux CE, Rytomaa M, Schulze A, McMahon M, Hill CS, Beug H and Downward J: Raf induces TGF $\beta$ production while blacking its apoptotic but not invasive responses: a mechanism leading to increased malignancy in epithelial cells. Genes Dev 14: 2610-2622, 2000.

39 Davies M, Robinson M, Smith E, Huntley S, Prime S and Paterson I: Induction of an epithelial to mesenchymal transition in human immortal and malignant keratinocytes by TGF1-b1 involves MAPK, Smad and AP-1 signalling pathways. J Cell Biochem 95: 918-931, 2005.

40 Grande M, Franzen A, Karlsson JO, Ericson LE, Heldin NE and Nilsson M: Transforming growth factor-b and epidermal growth factor synergistically stimulate epithelial to mesenchymal transition (EMT) through a MEK-dependent mechanism in primary cultured pig thyrocytes. J Cell Sci 115: 4227-4236, 2002.

41 Uttamsingh S, Bao X, Nguyen KT, Bhanot M, Gong J, Chan JL, Liu F, Chu TT and Wang LH: Synergistic effect between EGF and TGF $\beta 1$ in inducing oncogenic properties of intestinal epithelial cells. Oncogene 27: 2626-2634, 2008.

42 Daphu I, Horn S, Stieber D, Varughese JK, Spriet E, Dale HA, Skaftnesmo KO, Bjerkvig $\mathrm{R}$ and Thorsen $\mathrm{F}$ : In vitro treatment of melanoma brain metastasis by simultaneously targeting the MAPK and PI3K singaling pathways. Int J Mol Sci 15: 87738794, 2014.
43 Bakin AV, Tomlinson AK, Bhowmick NA, Moses HL and Arteaga CL: Phosphatidylinositol 3-kinase function is required for transforming growth factor-b-mediated epithelial to mesenchymal transition and cell migration. J Biol Chem 275: 36803-36810, 2000.

44 Lee YI, Kwon YJ and Joo CK: Integrin-linked kinase function is required for transforming growth factor $\mathrm{b}$-mediated epithelial to mesenchymal transition. Biochem Biophys Res Commun 316: 997-1001, 2004.

45 Rodriguez-Barbero A, Dorado F, Velasco S, Pandiella A, Banas $\mathrm{B}$ and Lopez-Novoa JM: TGF $\beta 1$ induces-COX-2 expression and PGE2 synthesis through MAPK and PI3K pathways in human mesangial cells. Kidney Int 70: 901-909, 2006.

46 Lien SC, Usami S, Chien S and Chiu JJ: Phosphatidylinositol 3-kinase/Akt pathway is involved in transforming growth factor-b1-induced phenotypic modulation of 10T1/2 cells to smooth muscle cells. Cell Signal 18: 1270-1278, 2006

47 Yeh YY, Chiao CC, Kuo WY, Hsiao YC, Chen YJ, Wei YY, Lai TH, Fong YC and Tang CH: TGF $\beta 1$ increases motility and avb3 integrin up-regulation via $\mathrm{PI} 3 \mathrm{~K}$, Akt and NF-kB dependent pathway in human chondrosarcoma cells. Biochem Pharmacol 75: 1292-1301, 2008.

48 Wu YJ, Pagel MA, Mildoon LL, Fu R and Neuwelt EA: High $\alpha v$ integrin level of cancer cells is associated with development of brain metastasis in athymic rats. Anticancer Res 37(8): 40294040, 2017.

49 Li Q, Yang J, Yu Q, Wu H, Liu B, Xiong H, Hu G, Zhao J, Yuan $\mathrm{X}$ and Liao Z: Associations between single-nucleotide polymorphisms in the PI3K-PTEN-AKT-mTOR pathway and increased risk of brain metastasis in patients with non-small cell lung cancer. Clin Cancer Res 19: 6252-6260, 2013.

50 Shin I, Bakin AV, Rodeck U, Brunet A and Arteaga CL: Transforming growth factor $b$ enhances epithelial cell survival via Akt-dependent regulation fo FKHRL1. Mol Biol Cell 12: 3328-3339, 2001.

51 Lamouille $\mathrm{S}$ and Derynck R: Cell size and invasion in TGF $\beta$ induced epithelial to mesenchymal transition is regulated by activation of the mTOR pathway. J Cell Biol 178: 437-451, 2007.

52 Kattla JJ, Carew RM, Heljic M, Godson C and Brazil DP: Protein kinase $\mathrm{B} / \mathrm{Akt}$ activity is involved in renal TGF $\beta 1$-driven epithelial-mesenchymal transition in vitro and in vivo. Am $\mathrm{J}$ Physiol Renal Physiol 295: F215-225, 2008.

53 Gulhati P, Cai Q, Li J, Liu J, Rychahou PG, Qiu S, Lee EY, Silva SR, Bowen KA, Gao $\mathrm{T}$ and Evers BM: Targeted inhibition of mammalian target of rapamycin signaling inhibits tumorigenesis of colorectal cancer. Clin Cancer Res 15: 72077126,2009

54 Gulhati P, Bowen KA, Liu J, Stevens PD, Rychahou PG, Chen M, Lee EY, Weiss HL, O'Connor KL, Gao T and Evers BM: mTORC1 and mTORC2 regulate EMT, motility, and metastasis of colorectal cancer via RhoA and Rac1 signaling pathways. Cancer Res 71: 3246-3256, 2011.

55 Yuge R, Kitadai Y, Shinagawa K, Onoyama M, Tanaka S, Yasui $\mathrm{W}$ and Chayama K: mTOR and PDGF pathway blockade inihibits liver metastasis of colorectal cancer by modulating the tumor microenvironment. The American J Pathol 185: 399-408, 2015.

56 Sipos F and Galamb O: Epithelial-to-mesenchymal and mesenchymal-to-epithelial transitions in the colon. World $\mathbf{J}$ Gastroenterol 18: 601-608, 2012. 
57 Kwasnicki A, Jeevan D, Braun A, Murali R and Jhanwar-Uniyal M: Involvement of mTOR signaling pathways in regulating growth and dissemination of metastatic brain tumors via EMT. Anticancer Res 35: 689-696, 2015.

58 Zhao H, Cui Kemi, Nie F, Wang L, Brandl MB, Jin G, Li F, Mao Y, Xue Z, Rodriguez A, Chang J and Wong ST: The effect of mTOR inhibition alone or combined with MEK inhibitors on brain metastasis: an in vivo analysis in triple-negative breast cancer models. Breast Cancer Res Treat 131: 425-436, 2012.

59 Gunaratne A, Thai BL and Diguglielmo GM: Atypical protein kinase $\mathrm{C}$ phosphorylates Par6 and facilitates transforming growth factor b-induced epithelial-to-mesenchymal transition. Molecular and Cellular Biology 33: 874-886, 2013.

60 Viloria-Petit Am, David L, Jia JY, Erdemir T, Bane AL, Pinnaduwage D, Roncari L, Narimatsu M, Bose R, Moffat J, Wong JW, Kerbel RS, O'Malley FP, Andrulis IL and Wrana JL: A role for the TGF $\beta$-Par6 polarity pathway in breast cancer progression. PNAS 106: 14028-14033, 2009.

61 Wilhelm I, Fazakas C, Molnar J, Hasko J, Vegh AG, Cervenak L, Nagyoszi P, Nyul-Toth A, Farkas AE, Bauer H, Guillemin GJ, Bauer HC, Varo G and Krizbai IA: Role of Rho/ROCK signaling in the interaction of melanoma cells with the bloodbrain barrier. Pigment Cell Melanoma Res 27: 113-123, 2014.

62 Sampieri K and Fodde R: Cancer stem cells and metastasis. Semin Cancer Biol 22: 187-193, 2012.

63 Xing F, Kobayashi A, Okuda H, Watabe M, Pai SK, Pandey PR, Hirota S, Wilber A, Mo YY, Moore BE, Liu W, Fekuda K, Iiizumi M, Sherma S, Liu Y, Wu K, Peralta E and Watabe K: Reactive astrocytes promote the metastatic growth of breast cancer stem-like cells by activating Notch signalling in the brain. EMBO Mol Med 5: 384-396, 2013.

64 Scheel C, Eaton EN, Li SH, Chaffer CL, Reinhardt F, Kah KJ, Bell G, Guo W, Robin J, Richardson AL and Weinberg RA: Paracrine and autocrine signals induce and maintain mesenchymal and stem cell states in the breast. Cell 145: 926940, 2011.

65 Fortini ME: Notch signaling: the core pathway and its posttranslational regulation. Dev Cell 16: 633-647, 2009.

66 Yuan X, Wu H, Han N, Xu H, Chu Q, Yu S, Chen Y and Wu $\mathrm{K}$ : Notch signaling and EMT in non-small cell lung cancer: biological significance and therapeutic application. J Hematol Oncol 7: 87, 2014.

67 Leong KG, Niessen K, Kulic I, Raouf A, Eaves C, Pollet I and Karsan A: Jagged1-mediated Notch activation induces epithelial-to-mesenchymal transition through Slug-induced repression of E-cadherin. J Exp Med 204: 2935-2948, 2007.

68 Vinson KE, George DC, Fender AW, Bertrand FE and Sigounas G: The Notch pathway in colorectal cancer. Int J Cancer 138: 1835-1842, 2016.

69 Zavadil J, Cermak L, Soto-Nieves $\mathrm{N}$ and Bottinger EP: Integration of TGF $\beta$ eta/Smad and Jagged $1 /$ Notch signaling in epithelial-to-mesenchymal transition. EMBO J 23: 1155-1165, 2004.

70 Sahlgren C, Gustafsson MV, Jin S, Poellinger L and Lendahl $\mathrm{U}$ : Notch signaling mediates hypoxia-induced tumor cell migration and invasion. Proc Natl Acad Sci USA 105: 63926397, 2008.

71 Zheng X, Linke S, Dias JM, Zheng X, Gradin K, Wallis TP, Hamilton BR, Gustafsson M, Ruas JL, Wilkins S, Bilton RL, Brismar K, Whitelaw ML, Pereira T, Gorman JJ, Ericson J, Peet
DJ, Lendahl $U$ and Poellinger L: Interaction with factor inhibiting HIF-1 defines an additional mode of cross-coupling between the Notch and hypoxia signaling pathways. Proc Natl Acad Sci USA 105: 3368-3373, 2008.

72 Ye YZ, Chang ZH, Fan XY, Xu XL, Chen ML, Chang BW and Zhang YB: Notch3 overexpression associates with poorp prognosis in human non-small0cell lung cancer. Med Oncol 30: 595, 2013.

73 Fender AW, Nutter JM, Bertrand FE and Sigounas G: Notch-1 promotes stemness and epithelial to mesenchymal transition in colorectal cancer. J Cell Biochem 116: 2517-2527, 2015.

74 Nam DH, Joen HM, Kim S, Kim MH, Lee YJ, Lee MS, Kim H, Joo KM, Lee DS, Price JE, Bang SI and Park WY: Activation of Notch signaling in a xenograft model of brain metastasis. Clin Cancer Res 14: 4059-4066, 2008.

75 McGowan PM, Simedrea C, Ribot EJ, Foster PJ, Palmieri D, Steeg PS, Allan AL and Chambers AF: Notch1 inhibition alters the CD44hi/CD24lo population and reduces the formation of brain metastases from breast cancer. Mol Cancer Res 9: 834-844, 2011.

76 Vermeulen L, De Sousa EMF, van der Heijden M, Cameron K, de Jong JH, Borovski T, Tuynman JB, Todaro M, Merz C, Rodermond H, Sprick MR, Kemper K, Richel DJ, Stassi G and Medema JP: Wnt activity defines colon cancer stem cells and is regulated by the microenvironment. Nat Cell Biol 12: 468-476, 2010.

77 Malanchi I, Peinado H, Kassen D, Hussenet T, Metzger D, Chambon P, Huber M, Hohl D, Cano A, Birchmeier W and Huelsken J: Cutaneous cancer stem cell maintenance is dependent on beta-catenin signalling. Nature 452: 650-653, 2008.

78 Reya T and Clevers H: Wnt signalling in stem cells and cancer. Nature 434: 843-850, 2005.

79 Zeng YA and Nusse R: Wnt proteins are self-renewal factors for mammary stem cells and promote their long-term expansion in culture. Cell Stem Cell 6: 568-577, 2010.

80 Fidler IJ: The role of the organ microenvironment in brain metastasis. Seminars in Cancer Biol 21: 107-112, 2011.

81 MacDonald BT, Tamai K and He X: Wnt/ $\beta$-catenin signaling: components, mechanisms, and diseaseas. Devel Cell 17: 9-26, 2009.

82 Miki T, Yasuda SY and Kahn M: Wnt/ $\beta$-catenin signaling in embryonic stem cell self-renewal and somatic cell reprogramming. Stem Cell Rev 7: 836-846, 2011.

83 Ghahhari NM and Babashah S: Interplay between microRNAs and $\mathrm{WNT} / \beta$-catenin signaling pathway regulates epithelialmesenchymal transition in cancer. Eur J Cancer 51: 1638-1649, 2015.

84 Heuberger J and Birchmeier W: Interplay of cadherin-mediated cell adhesion and canonical wnt signaling. Cold Spring Harbor Perspect Biol 2: a002915, 2010.

85 Yook JI, Li XY, Ota I, Fearon ER and Weiss SJ: Wnt-dependent regulation of the E-cadherin repressor Snail. J Biol Chem 280: 11740-11748, 2005.

86 Nelson WJ and Nusse R: Convergence of Wnt, $\beta$-catenin and cadherin pathways. Science 303: 1483-1487, 2004.

87 Liebner S, Cattelino A, Gallini R, Rudini N, Lurlaro M, Piccolo $\mathrm{S}$ and Dejana E: Beta-catenin is required for endothelialmesenchymal transformation during heart cushion development in the mouse. J Cell Biol 166: 59-367, 2004.

88 Li XY, Liu SL, Cha N, Zhao YJ, Wang SC, Li WN, Wang EH and Wu GP: Transcription expression and clinical significance of disheveled-3 mRNA and catenin mRNA in pleural effusions from patients with lung cancer. Clin Dev Immunol: 904946, 2012. 
89 Kafka A, Tomas D, Beros V, Pecina HI, Zeljko M and PecinaSlaus N: Brain metastases from lung cancer show increased expression of dvl1, dvl3 and beta-catenin and down-regulation of e-cadherin. Int J Mol Sci 15: 10635-10651, 2014.

90 Dey N, Barwick BG, Moreno CS, Ordanic-Kodani M, Chen Z, Oprea-Ilies G, Tang W, Catzavelos C, Kerstann KF, Sledge GW, Abramovitz M, Bouzyk M, De P and Leyland-Jones BR: Wnt signaling in triple negative breast cancer is associated with metastasis. BMC Cancer 13: 537, 2013.

91 Smid M, Wang Y, Zhang Y, Sieuwerts AM, Yu J, Klijn JGM, Foekens JA and Martens JWM: Subtypes of breast cancer show preferential site of relapse. Cancer Res 68: 3108-3114, 2008.

92 Zhang J, Tian XJ and J Xing: Signal transduction pathways of EMT induced by TGF $\beta$, SHH, and WNT and their crosstalks. J Clin Med 5: 41, 2016.

93 Huangfu D and Anderson KV: Signaling from Smo to Ci/Gli: conservation and divergence of hedgehog pathways from Drosophila to vertebrates. Development 133: 3-14, 2006.

94 Murone M, Rosenthal A and de Sauvage FJ: Sonic hedgehog signaling by the patched-smoothened receptor complex. Curr Biol 9: 76-84, 1999

95 Dennler S, Andre J, Alexaki I, Li A, Magnaldo T, ten Dijke P, Wang XJ, Verrecchia F and Mauviel A: Induction of sonic hedgehog mediators by transforming growth factor-b: smad3dependent activation of Gli2 and Gli1 expression in vitro and in vivo. Cancer Res 67: 6981-6986, 2007.

96 Alexaki VI, Javelaud D, van kempen LCL, Mohammad KS, Dennler S, Luciani F, Hoek KS, Juarez P, Goydos JS, Fournier PJ, Sibon C, Bertolotto C, Verrecchia F, Saule S, Delmas V, Ballotti R, Larue L, Saiag P, Guise TA and Mauviel A: Gli2mediated melanoma invasion and metastasis. J Natl Cancer Inst 102: 1148-1159, 2010.

97 Li X, Deng W, Nail CD, Bailey SK, Kraus MH, Ruppert JM and Lobo-Rupert SM: Snail induction is an early response to Gli1 that determines the efficiency of epithelial transformation. Oncogene 25: 609-621, 2006.

98 Yue D, Li H, Che J, Zhang Y, Tseng HH, Jin JQ, Luh TM, Giroux-Leprieur E, Mo M, Zheng Q, Shi H, Zhang H, Hao X, Wang C, Jablons DM and He B: Hedgehog/Gli promotes epithelial-mesenchymal transition in lung squamous cell carcinomas. J Experiment Clin Cancer Res 33: 34, 2014.

99 Bermudez O, Hennen E, Koch I, Lindner M and Eickelberg O: Gli1 mediates lung cancer cell proliferation and sonic hedgehog-dependent mesenchymal cell activation. PLoS ONE 8(5): e63226, 2013.

100 Maitah MY, Ali S, Ahmad A, Gadgeel S and Sarkar FH: Upregulation of sonic hedgehog contributes to TGF $\beta 1$-induced epithelial to mesenchymal transition in NSCLC cells. PLoS ONE 6: e16068, 2011.

101 Chou CH, Lieu AH, Wu CH, Chang LK, Loh JK, Lin RC, Chen WJ, Liao HD, Fu WS, Chang CS, Lin CC, Hsu CM, Chio CC, Howng SL and Hong YR: Differential expression of hedgehog signaling components and snail/e-cadherin in human brain tumors. Oncol Rep 24: 1225-1232, 2010.

102 Tang J, Li Y, Wang J, Wen Z, Lai M and Zhang H: Molecular mechanisms of microRNAs in regulating epithelial-mesenchymal transitions in human cancers. Cancer Letters 371: 301-313, 2016.

103 Zoni E, van der Pluijm G, Gray PC and Kruithof-de Julio M: Epithelial plasticity in cancer: unmasking a microRNA network for TGF $\beta$, Notch, and Wnt-mediated EMT. J Oncol: 198967, 2015.
104 Zhang B, Pan X, Cobb HP and Anderson TA: microRNAs as oncogenes and tumor suppressors. Dev Biol 302: 1-12, 2007.

105 Zaravinos A: The regulatory role of microRNAs in EMT and cancer. J Oncol: 865816, 2015.

106 Hurteau GJ, Carlson JA, Spivack SD and Brock GJ: Overexpression of the microRNA has-miR-200c leads to reduced expression of transcription factor 8 and increased expression of E-cadherin. Cancer Res 67: 7972-7976, 2007.

107 Korpal M, Lee ES, Hu G and Kang Y: The miR-200 family inhibits epithelial-mesenchymal transition and cancer cell migration by direct targeting of E-cadherin transcriptional repressors ZEB1 and ZEB2. J Biol Chem 283: 14910-14914, 2008.

108 Cong N, Du P, Zhang A, Shen F, Su J, Pu P, Wang T, Zjang J, Kang C and Zhang Q: Down-regulated microRNA-200a promotes EMT and tumor growth through the wnt/beta-catenin pathway by targeting the E-cadherin repressors ZEB1/ZEB2 in gastric adenocarcinoma. Oncol Rep 29: 1579-1587, 2013.

109 Sun Y, Shen S, Liu X, Tang H, Wang Z, Yu Z, Li X and Wu M: miR-429 inhibits cells growth and invasion and regulates EMTrelated marker genes by targeting Onecut 2 in colorectal carcinoma. Mol Cell Biochem 390: 19-30, 2014.

110 Pacurari M, Addison JB, Bondalapati N, Wan YW, Luo D, Qian Y, Castranova V, Ivanov AV and Guo NL: The microRNA-200 family targets multiple non-small cell lung cancer prognostic markers in H1299 cells and BEAS-2B cells. International J Oncol 43: 548-560, 2013.

111 Garofalo $\mathrm{M}$ and Croce CM: Role of microRNAs in maintaining cancer stem cells. Adv Drug Deliv Rev 81: 53-61, 2015.

112 Tu Y, Gao X, Li G, Fu H, Cui D, Liu H, Jin W and Zhang Y: MicroRNA-218 inhibits glioma invasion, migration, proliferation, and cancer stem-like cell self-renewal by targeting the polycomb group gene Bmi1. Cancer Res 73: 6046-6055, 2013.

113 Chen L, Chen XR, Chen FF, Liu Y, Li P, Zhang R, Yan K, Yi YJ, Xu ZM and Jiang XD: MicroRNA-107 inhibits U87 glioma stem cells growth and invasion. Cell Mol Neurobiol 33: 651657, 2013.

114 Zhao S, Deng Y, Liu Y, Chen X, Yang G, Mu Y, Zhang D, Kang $\mathrm{J}$ and $\mathrm{Wu} \mathrm{Z}$ : MicroRNA-153 is tumor suppressive in glioblastoma stem cells. Mol Biol Rep 40: 2789-98, 2013.

115 Ying Z, Li Y, Wu J, Zhu X, Yang Y, Tian H, Li W, Hu B, Cheng SY and Li M: Loss of miR-204 expression enhances glioma migration and stem cell-like phenotype. Cancer Res 73: 990999, 2013.

116 Iliopoulos D, Hirsch HA and Struhl K: An epigenetic switch involving NF-kappaB, Lin28, Let-7 MicroRNA, and IL6 links inflammation to cell transformation. Cell 139: 693-706, 2009.

117 Okuda H, Xing F, Pandey PR, Sharma S, Watabe M, Pai SK, Mo YY, Liizumi-Gairani M, Hirota S, Liu Y, Wu K, Pochampally R and Watabe K: miR-7 suppresses brain metastasis of breast cancer stem-like cells by modulating KLF4. Cancer Res 73: 1434-1444, 2013.

118 Fang Y, Xiang J, Chen Z, Gu X, Li Z, Tang F and Zhou Z: miRNA expression profile of colon cancer stem cells compared to non-stem cells using the SW1116 cell line. Oncol Rep 28: 2115-2124, 2012.

119 Miao Y, Li J, Qiu X, Li Y, Wang Z and Luan Y: miR-27a regulates the self-renewal of the H446 small cell lung cancer cell line in vitro. Oncol Rep 29: 161-168, 2013. 
120 Ji J, Yamashita T, Budhu A, Forgues M, Jia HL, Li C, Deng C, Wauthier E, Reid LM, Ye QH, Qin LX, Yang W, Wang HY, Tang ZY, Croce CM and Wang XW: Identification of microRNA-181 by genome-wide screening as a critical player in EpCAM-positive hepatic cancer stem cells. Hepatology 50: 472-480, 2009.

121 Zhang Y, Wang Z, Chen M, Peng L, Wang X, Ma Q, Ma F and Jiang B: MicroRNA-143 targets MACC1 to inhibit cell invasion and migration in colorectal cancer. Mol Cancer 11: 23, 2012.

122 Mueller WC, Spector Y, Edmonston TB, Cyr BS, Jaeger D, Lass U, Aharonov R, Rosenwald, S and uroChajut A: Accurate classification of metastatic brain tumors using a novel microRNA-based test. Oncologist 16: 165-174, 2011.

123 Rosenfeld N, Aharonov R, Meiri E, Rosenwald S, Spector Y, Zepeniuk M, Shabes N, Tabak S, Levy A, Lebanony D, Goren Y, Silberschein E, Targan N, Ben-Ari A, Gilad S, Sion-Vardy N, Tobar A, Feinmesser M, Kharenko O, Nativ O, Nass D, Perelman M, Yosepovich A, Shalmon B, Polak-Charcon S, Fridman E, Avniel A, Bentwich I, Bentwich Z, Cohen D, Chajut $A$ and Barshack I: MicroRNAs accurately identify cancer tissue origin. Nat Biotechnol 26: 462-469, 2008.

124 Alsidawi S, Malek E and Driscoll JJ: MicroRNAs in brain metastases: potential role as diagnostics and therapeutics. Int J Mol Sci 15: 10508-10526, 2014.

125 Subramani A, Alsidawi S, Jagannathan S, Sumita K, Sasaki AT, Aronow B, Warnick RE, Lawler and Driscoll JJ: The brain microenvironment negatively regulates miRNA-768-3p to promote K-ras expression and lung cancer metastasis. Scientific Reports 3: 2392, 2013.

126 Li Z, Peng Z, Gu S, Zheng J, Feng D, Qin Q and He J: Global analysis of miRNA-mRNA interaction network in breast cancer with brain metastasis. Anticancer Res 37(8): 4455-4468, 2017.

127 Zhang L, Sullivan PS, Goodman JC, Gunaratne PH and Marchetti D: MicroRNA-1258 suppresses breast cancer brain metastasis by targeting heparanase. Cancer Research 71: 645-654, 2011.

128 Ridgway LD, Wetzel MD, Ngo JA, Erdreich-Epstein A and Marchetti D: Heparanase-induced GEF-H1 signaling regulates the cytoskeletal dynamics of brain metastatic breast cancer cells. Mol Cancer Res 10: 689-702, 2012.

$129 \mathrm{Li} \mathrm{Z}, \mathrm{Gu} \mathrm{X}$, Fang Y, Xiang J and Chen Z: MicroRNA expression profiles in human colorectal cancers with brain metastases. Oncol Letters 3: 346-350, 2012.

130 Migliore C, Martin V, Leoni VP, Restivo A, Atzori L, Petrelli A, Isella C, Zorcolo L, Sarotto I, Casula G, Comoglio PM, Columbano A and Giordano S: MiR-1 down-regulation cooperates with MACC1 in promoting MET overexpression in human colon cancer. Clin Cancer Res 18: 737-747, 2012.

131 Zhu L, Chen H, Zhou D, Li D, Bai R, Zheng S and Ge W: MicroRNA-9 up-regulation in involved in colorectal cancer metastasis via promoting cell motility. Med Oncol 29: 10371043, 2012.

132 Ma L, Young J, Prabhala H, Pan E, Mestdagh P, Muth D, TeruyaFeldstein J, Reinhardt F, Onder TT, Valastyan S, Westermann F, Speleman F, Vandesompele J and Weinberg RA: miR-9, a MYC$\mathrm{MYCN}$-activated microRNA, regulates E-cadherin and cancer metastasis. Nat Cell Biol 12: 247-256, 2010.

133 Ahmad A, Sethi S, Chen W, Ali-Fehmi R, Mittal S and Sarkar FH: Up-regulation of microRNA-10b is associated with the development of breast cancer brain metastasis. Am J Transl Res 6(4): 384-390, 2014.
134 Heinzelmann J, Unrein A, Wickmann U, Baumgart S, Stapg M, Szendroi A, Grimm MO, Gajda MR, Wunderlich $\mathrm{H}$ and Junker K: MicroRNAs with prognostic potential for metastasis in clear cell renal cell carcinoma: a comparison of primary tumors and distant metastases. Ann Surg Oncol 21: 10461054,2014

135 Hanniford D., Zhong J, Koetz L, Gaziel-Sovran A, Lackaye DJ, Shang S, Pavlick A, Shapiro R, Berman R, Darvishian F, Shao Y, Osman I and Hernando E: A miRNA-based signature detected in primary melanoma tissue predicts development of brain metastasis. Clin Cancer Res 21: 49034912, 2015.

136 Wang Q, Li X, Zhu Y and Yang P: MicroRNA-16 suppresses epithelial-mesenchymal transition-related gene expression in human glioma. Mol Med Rep 10: 3310-3314, 2014.

137 Camacho L, Guerrero P and Marchetti D: MicroRNA and protein profiling of brain metastasis competent cell-derived exosomes. PLoS ONE 8(9): e73790, 2013.

138 Lin Q, Chen T, Lin Q, Lin G, Lin J, Chen G and Guo L: Serum miR-19a expression correlates with worse prognosis of patients with non-small cell lung cancer. J Surg Oncol 107: 767-771, 2013.

139 Ahmad A, Ginnebaugh KR, Sethi S, Chen W, Ali R, Mittal S and Sarkar FH: miR-20b is up-regulated in brain metastases from primary breast cancers. Oncotarget 6(14): 12188-12195, 2015.

140 Zhou W, Shi G, Zhang Q, Wu Q, Li B and Zhang Z: MicroRNA-20b promotes cell growth of breast cancer cells partly via targeting phosphatase and tensin homologue (PTEN). Cell Biosci 4: 62, 2014.

141 Singh M, Garg N, Venugopal C, Hallett R, Tokar T, McFarlane N, Mahendram S, Bakhshinyan D, Manoranjan B, Vora P, Qazi M, Arpin CC, Page B, Haftchenary S, Rosa DA, Lai PS, Gomez-Biagi RF, Ali AM, Lewis A, Geletu M, Murty NK, Hassell JA, Jurisica I, Gunning PT and Singh SK: STAT3 pathway regulates lung-derived brain metastasis initiating cell capacity through miR-21 activation. Oncotarget 6: 2746127477, 2015

142 Li B, Song Y, Liu TJ, Cui YB, Jiang Y, Xie ZS and Xie SL: miRNA-22 suppresses colon cancer cell migration and invasion by inhibiting the expression of T-cell lymphoma invasion and metastasis 1 and matrix metalloproteinases 2 and 9. Oncol Rep 29: 1932-1938, 2013.

143 Almeida MI, Nicoloso MS, Zeng L, Ivan C, Spizzo R, Gafà R, Xiao L, Zhang X, Vannini I, Fanini F, Fabbri M, Lanza G, Reis RM, Zweidler-McKay PA and Calin GA: Strand-specific miR28-5p and miR-28-3p have distinct effects in colorectal cancer cells. Gastroenterology 142(4): 886-896, 2012.

144 Nguyen T, Kuo C, Nicholl MB, Sim MS, Turner RR, Morton DL and Hoon DSB: Down-regulation of microRNA-29c is associated with hypermethylation of tumor-related genes and disease outcome in cutaneous melanoma. Epigenetics 6: 388394, 2011.

145 Yan LX, Huang XF, Shao Q, Huang MY, Deng L, Wu QL, Zeng YX and Shao JY: MicroRNA miR-21 overexpression in human breast cancer is associated with advanced clinical stage, lymph node metastasis and patient poor prognosis. RNA 14 : 2348-2360, 2008.

146 Cottonham CL, Kaneko S and Xu L: miR-21 and miR-31 converge on TIAM1 to regulate migration and invasion of colon carcinoma cells. J Biol Chem 285: 35293-35302, 2010. 
147 Hwang SJ, Lee HW, Kim HR, Song HJ, Lee DH, Lee H, Shin $\mathrm{CH}$, Joung JG, Kim DH, Joo KM and Kim HH: Overexpression of microRNA-95-3p suppresses brain metastasis of lung adenocarcinoma through down-regulation of cyclin D1. Oncotarget 6: 20434-20448, 2015.

148 Li N, Tang A, Huang S, Li Z, Li X, Shen S, Ma J and Wang X: MiR-126 suppresses colon cancer cell proliferation and invasion via inhibiting RhoA/ROCK signaling pathway. Mol Chem Biochem 380: 107-119, 2013.

149 Lin CW, Li XR, Zhang Y, Hu G, Guo YH, Zhou JY, Du J, Lv L, Gao K, Zhang Y and Deng H: Tap63 suppress metastasis via miR133b in colon cancer cells. Br J Cancer 110: 2310-2320, 2014.

150 Donzelli S, Mori F, Bellissimo T, Sacconi A, Casini B, Frixa T, Roscilli G, Aurisicchio L, Facciolo F, Pompili A, Carosi MA, Pescarmona E, Segatto O, Pond G, Muti P, Telera S, Strano S, Yarden Y and Blandino G: Epigenetic silencing of miR-145-5p contributes to brain metastasis. Oncotarget 6: 35183-35201, 2015.

151 Zhao C, Xu, Y, Zhang Y, Tan W, Xu J, Yang Z, Zhang Y, Lu Y and $\mathrm{Hu} \mathrm{X}$ : Down-regulation of miR-145 contributes to lung adenocarcinoma cell growth to form brain metastases. Oncol Rep 30: 2027-2034, 2013.

152 Hwang SJ, Seol HJ, Park YM, Kim KH, Gorospe M, Nam DH and Kim HH: MicroRNA-146a suppresses metastatic activity in brain metastasis. Mol Cells 34: 329-334, 2012.

153 Segura MF, Belitskaya-Lévy I, Rose AE, Zakrzewski J, Gaziel A, Hanniford D, Darvishian F, Berman RS, Shapiro RL, Pavlick AC, Osman I and Hernando E: Melanoma microRNA signature predicts post-recurrence survival. Clin Cancer Res 16: 15771586, 2010.

154 Remon J, Alvarez-Berdugo D, Majem M, Moran T, Reguart N and Lianes P: miRNA-197 and miRNA-184 are associated with brain metastasis in EGFR-mutant lung cancers. Clin Transl Oncol 18: 153-159, 2016.

155 Liu Z, Mai C, Yang H, Zhen Y, Yu X, Hua S, Wu Q, Jiang Q, Zhang Y, Song X and Fang W: Candidate tumour suppressor CCDC19 regulates miR-184 direct targeting of C-Myc thereby suppressing cell growth in non-small cell lung cancers. J Cell Mol Med 18: 1667-1679, 2014.

156 Du L, Schageman JJ, Subauste MC, Saber B, Hammond SM, Prudkin L, Wistuba II, Ji L, Roth JA, Minna JD and Pertsemlidis A: miR-93, miR-98 and miR-197 regulate expression of tumor suppressor gene FUS1. Mol Cancer Res 7: 1234-1243, 2009.

157 Wu X, Weng L, Li X, Guo C, Pal SK, Jin JM, Li Y, Nelson RA, Mu B, Onami SH, Wu JJ, Ruel NH, Wilczynski SP, Gao H, Covarrubias M, Figlin RA, Weiss LM and Wu H: Identification of a 4-microRNA signature for clear cell renal cell carcinoma metastasis and prognosis. PLoS One 7: e35661, 2012.

158 Huang J, Dong B, Zhang J, Kong W, Chen Y, Xue W, Liu D and Huang Y: miR-199a-3p inhibits hepatocyte growth factor/cMet signaling in renal cancer carcinoma. Tumour Biol 35: 5833-5843, 2014.

159 Teplyuk NM, Mollenhauer B, Gabriely G, Giese A, Kim E, Smolsky M, Kim RY, Saria MG, Pastorino S, Kesari S, and Krichevsky AM: MicroRNAs in cerebrospinal fluid identify glioblastoma and metastatic brain cancers and reflect disease activity. Neuro-Oncology 14: 689-700, 2012.

160 Ono S, Oyama T, Lam S, Chong K, Foshag LJ and Hoon DS: A direct plasma assay of circulating microRNA-210 of hypoxia can identify early systemic metastasis recurrence in melanoma patients. Oncotarget 6: 7053-7064, 2015.
161 Zhang Z, Sun H, Dai H, Walsh RM, Imakura M, Schelter J, Burchard J, Dai X, Chang AN, Diaz RL, Marszalek JR, Bartz SR, Carleton M, Cleary MA, Linsley PS and Grandori C: MicroRNA miR-210 modulates cellular response to hypoxia through the MYC antagonist MNT. Cell Cycle 8: 2756-2768, 2009.

162 Arora S, Ranade AR, Tran NL, Nasser S, Sridhar S, Korn RL, Ross JT, Dhruv H, Foss KM, Sibenaller Z, Ryken T, Gotway $\mathrm{MB}, \mathrm{Kim} \mathrm{S}$ and Weiss GJ: MicroRNA-328 is associated with (non-small) cell lung cancer (NSCLC) brain metastasis and mediates NSCLC migration. Int J Cancer 129(11): 2621-2631, 2011.

163 Chen LT, Xu SD, Xu H, Zhang JF, Ning JF and Wang SF: MicroRNA-378 is associated with non-small cell lung cancer brain metastasis by promoting cell migration, invasion and tumor angiogenesis. Med Oncol 29: 1673-1680, 2011.

164 Xing F, Sharma S, Liu Y, Mo YY, Wu K, Zhang YY, Pochampally R, Martinez LA, Lo HW and K Watabe: miR509 suppresses brain metastasis of breast cancer cells by modulating RhoC and TNFa. Oncogene 34: 4890-4900, 2015.

165 Rang Z, Yang G, Wang YW and Cui F: MiR-542-3p suppresses invasion and metastasis by targeting the proto-oncogene serine/threonine protein kinase, PIM1, in melanoma. Biochem Biophys Res Commun 474: 315-320, 2016.

166 Ramaswamy S, Tamayo P, Rifkin R, Mukherjee S, Yeang CH, Angelo M, Ladd C, Reich M, Latulippe E, Mesirov JP, Poggio T, Gerald W, Loda M, Lander ES and Golub TR: Multiclass cancer diagnosis using tumor gene expression signatures. PNAS 98: 15149-15154, 2001.

167 Fidler IJ and Kripke ML: Metastasis results from preexisting variant cells within a malignant tumor. Science 197: 893-895, 1977.

168 Minn AJ, Kang Y, Serganova I, Gupta GP, Giri DD, Doubrovin M, Ponomarev V, Gerald WL, Blasberg R and Massague J: Distinct organ-specific metastatic potential of individual breast cancer cells and primary tumors. J Clinl Invest 115: 44-55, 2005.

169 Niikura N, Saji S, Tokuda Y and H Iwata: Brain metastases in breast cancer. Jpn J Clin Oncol 44: 1133-1140, 2014.

170 Bendell JC, Domchek SM, Burstein HJ, Harris L, Younger J, Kutler I, Bunnell C, Rue M, Gelman R and Winer E: Central nervous system metastases in women who receive trastuzumabbased therapy for metastatic breast cacercinoma. Cancer 97: 2972-2977, 2003.

171 Brufsky AM, Mayer M, Rugo HS, Kaufman PA, Tan-Chiu E, Tripathy D, Tudor IC, Wang LI, Brammer MG, Shing M, Yood MU and Yardley DA: Central nervous system metastases in patients with HER2-positive metastatic breast cancer: incidence, treatment, and survival in patients from regisHER. Clin Cancer Res 17: 4834-4843, 2011.

172 Olson EM, Najita JS, Sohl J, Arnaout A, Burstein HJ, Winer EP and Lin NU: Clinical outcomes and treatment practice patterns of patients with HER2-positive metastatic breast cancer in the post-trastuzumab era. Breast 22: 525-531, 2013.

173 Olson EM, Abdel-Rasoul M, Maly J, Wu CS, Lin NU and Shapiro CL: Incidence and risk of central nervous systemic metastases as site of first recurrence in patients with Her2positive breast cancer treated with adjuvant trastuzumab. Ann Oncol 24: 1526-1533, 2013. 
174 Pestalozzi BC, Holmes E, de Azambuja E, Metzger-Filho O, Hogge L, Scullion M, Lang I, Wardley A, Lichinitser M, Sanchez RI, Muller V, Dodwell D, Gelber RD, Piccart-Gebhart MJ and Cameron D: CNS relapses in patients with HER2positive early breast cancer who have and have not received adjuvant trastuzumab: a retrospective substudy of the HERA trial (BIG 1-01). Lancet Oncol 14: 244-248, 2013.

175 Lin NU, Amiri-Kordestani L, Palmieri D, Liewehr DJ and Steeg PS: CNS metastases in breast cancer: old challenge, new frontiers. Clin Cancer Res 19: 6404-6418, 2013.

176 Vaz-Luis I, Ottesen RA, Hughes ME, Marcom PK, Moy B, Rugo HS, Theriault RL, Wilson J, Niland JC, Weeks JC and Lin NU: Impact of hormone receptor status on patterns of recurrence and clinical outcomes among patients with human epidermal growth factor-2-positive breast cancer in the National Comprehensive Cancer Network: a prospective cohort study. Breast Cancer Res 14: R129, 2012.

177 Metro G, Foglietta J, Russillo M, Stocchi L, Vidiri A, Giannarelli D, Crino L, Papaldo P, Mottolese M, Cognetti F, Fabi A and Gori S: Clinical outcome of patients with brain metastases from HER2-positive breast cancer treated with lapatinib and capecitabine. Ann Oncol 22: 625-630, 2010.

178 Pessina F, Navarria P, Cozzi L, Franceschini D, Tomatis S, Clerici E, Ascolese AM, DE Rose F, Bello L, Masci G, Santoro A and Scorsetti M: Outcome evaluation of HER2 breast cancer patients with limited brain metastasis. Anticancer Res 37(12): 7057-7062, 2017.

179 Dawood S, Broglio K, Esteva FJ, Ibrahim NK, Kau SW, Islam R, Aldape KD, Yu TK, Hortobagyi GN and Gonzalez-Angulo AM: Defining prognosis for women with breast cancer and CNS metastases by HER2 status. Ann Oncol 19: 1242-1248, 2008.

180 Kennecke H, Yerushalmi R, Woods R, Cheang MC, Voduc D, Speers $\mathrm{CH}$, Nielsen TO and Gelmon K: Metastatic behavior of breast cancer subtypes. J Clin Oncol 28: 3271-3277, 2010.

181 Lee LJ, Alexander B, Schnitt SJ, Comander A, Gallagher B, Garber JE and Tung N: Clinical outcome of triple negative breast cancer in BRCA1 mutation carriers and noncarriers. Cancer 117: 3093-3100, 2011.

182 Lin NU, Claus E, Sohl J, Razzak AR, Arnaout A and Winer EP: Sites of distant recurrence and clinical outcomes in patients with metastatic triple-negative breast cancer: high incidence of central nervous system metastases. Cancer 113: 2638-2645, 2008.

183 Anders CK, Deal AM, Miller CR, Khorram C, Meng H, Burrows E, Livasy C, Fritchie K, Ewend MG, Perou CM and Carey LA: The prognostic contribution of clinical breast cancer subtype, age, and race among patients with breast cancer brain metastases. Cancer 117: 1602-1611, 2011.

184 Bos PD, Zhang XHF, Nadal C, Shu W, Gomis RR, Nguyen DX, Minn AJ, van de Vijver MJ, Gerald WL, Foekens JA and Massague J: Genes that mediate breast cancer metastasis to the brain. Nature 459: 1005-1012, 2009.

185 Karrison TG, Ferguson DJ and Meier P: Dormancy of mammary carcinoma after mastectomy. J Natl Cancer Inst 91 : 80-85, 1999.

186 Schmidt-Kittler O, Ragg T, Daskalakis A, Granzow M, Ahr A, Blankenstein TJ, Kaufmann M, Diebold J, Arnholdt H, Muller P, Bischoff J, Harich D, Schlimok G, Riethmuller G, Eils R and Klein CA: From latent disseminated cells to overt metastasis: genetic analysis of systemic breast cancer progression. Proc Natl Acad Sci USA 100: 7737-7742, 2003.
187 Lee JY, Park K, Lim SH, Kim HS, Yoo KH, Jung KS, Song HN, Hong M, Do IG, Ahn T, Lee SK, Bae SY, Kim SW, Lee JE, Nam SJ, Kim DH, Jung HH, Kim JY, Ahn JS, Im YH and Park YH: Mutational profiling of brain metastasis from breast cancer: matched pair analysis of targeted sequencing between brain metastasis and primary breast cancer. Oncotarget 6 : 43731-43742, 2015.

188 Lo NG, Vivenza D< Monteverde M, Lattanzio L, Gojis O, Garrone O, Comino A, Merlano M, Quinlan PR, Syed N, Purdie CA, Thompson A, Palmieri $\mathrm{C}$ and Crook T: High frequency of complex TP53 mutations in CNS metastases from breast cancer. Br J Cancer 106: 397-404, 2012.

189 Woditschka S, Evans L, Duchnowska R, Tiffany Reed L, Palmieri D, Qian Y, Badve S, Sledge Jr G, Gril B, Aladjem MI, Fu H, Flores NM, Gokmen-Polar Y, Biernat W, SzutowiczZielinska E, Mandat T, Trojanowski T, Och W, CzartoryskaArlukowicz B, Jassem J, Mitchell JB and Steeg PS: DNA double-strand break repair genes and oxidative damage in brain metastasis of breast cancer. JNCI 106: dju145, 2014.

190 Pangeni RP, Channathodiyil P, Huen DS, Eagles LW, Johal BK, Pasha D, Hadjistephanou N, Nevell O, Davies CL, Adewumi AI, Khanom H, Samra IS, Buzatto VC, Chandrasekaran P, Shinawi T, Dawson TP, Ashton KM, Davis C, Brodbelt AR, Jenkinson MD, Bieche I, Latif F, Darling JL, Warr TJ and Morris MR: The GALNT9, BNC1 and CCDC8 genes are frequently epigenetically dysregulated in breast tumours that metastasise to the brain. Clin Epigenet 7: 57, 2015.

191 Feuerborn A, Mathow D, Srivastava PK, Gretz N and Grone HJ: Basonuclin-1 modulates epithelial plasticity and TGFßeta1induced loss of epithelial cell integrity. Oncogene 34: 11851195, 2015.

192 Fidler IJ, Yano S, Zhang R, Fujimaki T and CD Bucana: The seed and soil hypothesis: vascularization and brain metastases. Lancet Oncol 3: 53-57, 2002.

193 Qin H, Wang C, Jiang Y, Zhang X, Zhang Y and Ruan Z: Patients with single brain metastasis from non-small cell lung cancer equally benefit form stereotactic radiosurgery and surgery: a systematic review. Med Science Monitor 21: 144$152,2015$.

194 Mandell L, Hilaris B, Sullivan M, Sundaresan N, Nori D, Kim $\mathrm{JH}$, Martini N and Fuks Z: The treatment of single brain metastasis from non-oat cell lung carcinoma. Cancer 58: 641649, 1986.

195 Cai Y, Wang JY and Liu H: Clinical observation of whole brain radiotherapy concomitant with targeted therapy for brain metastasis in non-small cell lung cancer patients with chemotherapy failure. Asian Pac J Cancer Prev 14(10): 56995703, 2013.

196 Kikuchi T, Daigo Y, Ishikawa N, Katagiri T, Tsunoda T, Yoshida $\mathrm{S}$ and Nakamura Y: Expression profiles of metastatic brain tumor from lung adenocarcinomas on cDNA microarray. Int J Oncol 28: 799-805, 2006.

197 Zohrabian VM, Nandu H, Gulati N, Khitrov G, Zhao C, Mohan A, Demattia J, Braun A, Das K, Murali R and Jhanwar-Uniyal $\mathrm{M}$ : Gene expression profiling of metastatic brain cancer. Oncol Rep 18: 321-328, 2007.

198 Hazan RB, Phillips GR, Qiao RF, Norton L and Aaronson SA: Exogenous expression of $\mathrm{N}$-cadherin in breast cancer cells induces cell migration, invasion, and metastasis. J Cell Biol 148: 779-90, 2000. 
199 Qi J, Chen N, Wang J and Siu CH: Transendothelial migration of melanoma cells involves N-cadherin-mediated adhesion and activation of the $\beta$-catenin signaling pathway. Mol Biol Cell 16: 4386-4397, 2005.

200 Zhao N, Wilkerson MD, Shah U, Yin X, Wang A, Hayward MC, Roberts P, Lee CB, Parsons AM, Thorne LB, Hithcock BE, Grilley-Olson JE, Stinchcombe TE, Funkhouser WK, Wong KK, Sharpless NE and Hayes DN: Alterations of LKB1 and KRAS and risk of brain metastasis: comprehensive characterization by mutation analysis, copy number, and gene expression in nonsmall-cell lung carcinoma. Lung Cancer 86: 255-261, 2014.

$201 \mathrm{Li} \mathrm{F}$, Sun L and Zhang S: Acquirement of DNA copy number variations in non-small cell lung cancer metastasis to the brain. Oncol Rep 24: 1701-1707, 2015.

202 Lee HW, Scol HJ, Choi YL, Ju HJ, Joo KM, Ko YH, Lee JI and Nam DH: Genomic copy number alterations associated with the early brain metastasis of non-small cell lung cancer. Int J Oncol 41: 2013-2020, 2012.

203 Takamori S, Toyokawa G, Okamaoto I, Takada K, Kinoshita F, Kozuma Y, Matsubara T, Haratake N, Akamine T, Mukae N, Hirai F, Tagawa T, Oda Y, Iwaki T, Iihara K, Nakanishi Y and Maekara Y: Clinical significance of PD-L1 expression in brain metastases from non-small cell lung cancer. Anticancer Res 38(1): 553-557, 2018.

204 Zhang I, Zaorsky NG, Palmer JD, Mehra R and Lu B: Targeting brain metastases in ALK-rearranged non-small-cell lung cancer. Lancet Oncol 16: e510-e521, 2015.

205 Slotman B, Faivre-Finn C, Kramer G, Rankin E, Snee M, Hatton M, Postmus P, Collette L, Musat E and Senan S: Prophylactic cranial irradiation in extensive small-cell lung cancer. N Engl J Med 357: 664-672, 2007.

206 Doebele RC, Lu X, Sumey C, Maxson DA, Weickhardt AJ, Oton AB, Bunn PA Jr, Baron AE, Franklin WA, Aisner DL, Varella-Garcia M and Camidge DR: Oncogene status predicts patterns of metastatic spread in treatment-naïve nonsmall cell lung cancer. Cancer 118: 4502-4511, 2012.

207 Solomon B: Refining the toxicity profile of crizotinib. J Thorac Oncol 9: 1596-1597, 2014.

208 Isozaki H, Takigawa N and Kiura K: Mechanisms of acquired resistance to ALK inhibitors and the rationale for treating ALKpositive lung cancer. Cancers (Basel) 7: 763-783, 2015.

209 Costa DB, Kobayashi S, Pandya SS, Yeo WL, Shen Z, Tan W and Wilner KD: CSF concentration of the anaplastic lymphoma kinase inhibitor crizotinib. J Clin Oncol 29: e443-e445, 2011.

210 Chuan Tang S, Nguyen LN, Sparidans RW, Wagenaar E, Beijnen JH and Schinkel AH: Increased oral availability and brain accumulation of the ALK inhibitor crizotinib by coadministration of the P-glycoprotein $(\mathrm{ABCB} 1)$ and breast cancer resistance protein (ABCG2) inhibitor elacridar. Int $\mathrm{J}$ Cancer 134: 1484-1494, 2014.

211 Shaw AT, Mehra R, Tan DSW, Felip E, Chow LQM, Camidge DR, Vansteenkiste J, Sharma S, De Pas T, Riely GJ, Solomon BJ, Wolf J, Thomas M, Schuler M, Liu G, Santoro A, Geraldes M, Sen P, Boral AJ, Yovine A and Kim DW: Ceritinib (LDK378) for treatment of patients with ALK-rearranged (ALK+) nonsmall cell lung cancer (NSCLC) and brain metastases (BM) in the ASCEND-1 trial. Neuro Oncol 16(suppl 5): v39, 2014.

212 Seto T, Hida T, Nakagawa K, Satouchi M, Nishio M, Hotta K, Murakami H, Ohe Y, Takeda K, Tatsuno M, Shimada T, Tanaka $\mathrm{T}$ and Tamura $\mathrm{T}$ : Anti-tumor activity of alectinib in crizotinib pre-treated ALK-rearranged NSCLC in JP28927 study. Ann Oncol 25: iv426-470, 2014.

213 Gettinger SN, Bazhenova L, Salgia R, Langer C, Gold K, Rosell R, Shaw A, Weiss GJ, Narasimhan NI, Dorer DJ, Rivera V, Clackson T, Haluska FG and Camidge R: ALK inhibitor AP26113 in patients with advanced malignancies, including ALK+ non-small cell lung cancer (NSCLC): updated efficacy and safety data. Ann Oncol 25: iv426-470, 2014.

214 Zou HY, Friboulet L, Kodack DP, Engstrom LD, Li Q, West M, Tang RW, Wang H, Tsaparikos K, Wang J, Timofeevski S, Katayama R, Dinh DM, Lam H, Lam JL, Yamazaki S, Hu W, Patel B, Bezwada D, Frias RL, Lifshits E, Mahmood S, Gainor JF, Affolter T, Lappin PB, Gukasyan H, Lee N, Deng S, Jain RK, Johnson TW, Shaw AT, Fantin VR and Smeal T: PF06463922, an ALK/ROS1 inhibitor, overcomes resistance to first and second generation ALK inhibitors in preclinical models. Cancer Cell 28: 70-81, 2015.

215 Infarinato NR, Park JH, Krytska K, Ryles HT, Sano R, Szigety KM, Li Y, Zou HY, Lee NV, Smeal T, Lemmon MA and Mossé YP: The ALK/ROS1 inhibitor PF-06463922 overcomes primary resistance to crizotinib in ALK-driven neuroblastoma. Cancer Discov 6: 96-107, 2016.

216 Chen G, Chakravarti N, Aardalen K, Lazar AJ, Tetzlaff MT, Wubbenhorst B, Kim SB, Kopetz S, Ledoux AA, Vashisht Gopal YN, Pereira CG, Deng W, Lee JS, Nathanson KL, Aldape KD, Prieto VG, Stuart D and Davies MA: Molecular profiling of patient-matched brain and extracranial melanoma metastases implicates the PI3K pathway as a therapeutic target. Clin Cancer Res 20(21): 5537-5546, 2014.

217 Skibber JM, Soong SJ, Austin L, Balch CM and Sawaya RE: Cranial irradiation after surgical excision of brain metastases in melanoma patients. Ann Surg Oncol 3: 118-123, 1996.

218 Sampson JH, Carter JH, Friedman AH and Seigler HF: Demographics, prognosis, and therapy in 702 patients with brain metastases from malignant melanoma. J Neurosurg 88 : 11-20, 1998.

219 Riker AI, Enkemann SA, Fodstad O, Liu S, Ren S, Morris C, Xi Y, Howell P, Metge B, Samant RS, Shevde LA, Li W, Eschrich $\mathrm{S}$, Daud A, Ju J and Matta J: The gene expression profiles of primary and metastatic melanoma yields a transition point of tumor progression and metastasis. BMC Med Genom 1: 13, 2008.

220 Davies H, Bignell GR, Cox C, Stephens P, Edkins S, Clegg S, Teague J, Woffendin H, Garnett MJ, Bottomley W, Davis N, Dicks E, Ewing R, Floyd Y, Gray K, Hall S, Hawes R, Hughes J, Kosmidou V, Menzies A, Mould C, Parker A, Stevens C, Watt S, Hooper S, Wilson R, Jayatilake H, Gusterson BA, Cooper C, Shipley J, Hargrave D, Pritchard-Jones K, Maitland N, ChenevixTrench G, Riggins GJ, Bigner DD, Palmieri G, Cossu A, Flanagan A, Nicholson A, Ho JW, Leung SY, Yuen ST, Weber BL, Seigler HF, Darrow TL, Paterson H, Marais R, Marshall CJ, Wooster R, Stratton MR and Futreal PA: Mutations in the BRAF gene in human cancer. Nature 417: 949-954, 2002.

221 Casula M, Colombino M, Satta MP, Cossu A, Ascierto PA, Bianchi-Scarra G, Castiglia D, Budroni M, Rozzo C, Manca A, Lissia A, Carboni A, Petretto E, Satriano SM, Botti G, Mantelli M, Ghiorzo P, Stratton MR, Tanda F and Palmieri G: BRAF gene is somatically mutated but does not make a major contribution to malignant melanoma susceptibility: the Italian melanoma intergroup study. J Clin Onol 22: 286-292, 2004. 
222 Fonkem E, Uhlmann EJ, Floyd SR, Mahadevan A, Kasper E, Eton $\mathrm{O}$ and Wong ET: Melanoma brain metastasis: overview of current management and emerging targeted therapies. Expert Rev Neurother 12: 1207-1217, 2012.

223 Colombino M, Capone M, Lissia A, Cossu A, Rubino C, DeGiorgi VD, Massi D, Fonsatti E, Staibano S, Nappi O, Pagani E, Casula M, Manca A, Sini M, Franco R, Botti G, Caraco C, Mozzillo N, Ascierto PA and Palmieri G: BRAF/NRAS mutation frequencies among primary tumors and metastases in patients with melanoma. J Clin Oncol 30: 2522-2529, 2012.

224 El-Osta H, Falchook G, Tsimberidou A, Hong D, Naing A, Kim $\mathrm{K}$, Wen S, Janku $\mathrm{F}$ and Kurzrock R: BRAF mutations in advanced cancers: clinical characteristics and outcomes. PLoS ONE 6: 1-13, 2011.

225 Lin J, Jandial R, Nesbit A, Badie B and Chen M: Current and emerging treatments for brain metastases. Cancer Netw 29: 1$11,2015$.

226 Davies MA, Stemke-Hale K, Lin E, Tellez C, Deng W, Gopal YN, Woodman SE, Calderone TC, Ju Z, Lazar AJ, Prieto VG, Aldape K, Mills GB and Gershenwald JE: Integrated molecular and clinical analysis of AKT activation in metastatic melanoma. Clin Cancer Res 15: 7538-7546, 2009.

227 Huang FJ, Steeg PS, Price JE, Chiu WT, Chou PC, Xie K, Sawaya R and Huang S: Molecular basis for the critical role of suppressor of cytokine singaling-1 in melanoma brain metastasis. Cancer Res 68: 9634-9642, 2008.

228 Jemal A, Bray F, Center MM, Ferlay J, Ward E and Forma D: Global cancer statistics. CA: Cancer J Clin 61: 69-90, 2011.

229 Damiens K, Ayoub JPM, Lemieux B, Aubin F, Saliba W, Campeau MP and Tehfe M: Clinical features and course of brain metastases in colorectal cancer: an experience from a single institution. Curr Oncol 19: 254-258, 2012.

230 Vatandoust S, Price TJ and Karapetis CS: Colorectal cancer: metastases to a single organ. World J Gastroenterol 21: 1176711776, 2015.

231 Schouten LJ, Rutten J, Huveneers HA and Twijnstra A: Incidence of brain metastases in a cohort of patients with carcinoma of the breast, colon, kidney, and lung and melanoma. Cancer 94: 2698-2705, 2002.

232 Alden TD, Gianino JW and Saclarides TJ: Brain metastases from colorectal cancer. Dis Colon Rectum 39: 541-545, 1996.

233 Kye BH, Kim HJ, Kang WK, Cho HM, Hong YK, and Oh ST: Brain metastases from colorectal cancer: the role of surgical resection in selected patients. Colorectal Dis 14: e378-e385, 2012.

234 Farnell GF, Buckner JC, Cascino TL, O'Connell MJ, Schomberg PJ and Suman V: Brain metastases from colorectal carcinoma. The long term survivors. Cancer 78: 711-716, 1996.

235 Kruser TJ, Chao ST, Elson P, Barnett GH, Vogelbaum MA, Angelov L, Weil RJ, Pelley R and Suh JH: Multidisciplinary management of colorectal brain metastases: a retrospective study. Cancer 113: 158-165, 2008.

236 Schoeggl A, Kitz K, Reddy M and Zauner C: Stereotactic radiosurgery for brain metastases from colorectal cancer. Int $\mathrm{J}$ Colorectal Dis 17: 150-155, 2002.

237 Tran B, Kopetz S, Tie J, Gibbs P, Jiang Z, Lieu CH, Agarwal A, Maru D, Sieber O and J Desai: Differences in sites of metastatic disease and outcomes observed in patients with BRAF mutatnt colorectal cancers. J Clin Oncol 28: 15s, 2010.

238 Guo Q, Zhao Y, Chen J, Hu J, Wang S, Zhang D and Sun Y: BRAF-activated long non-coding RNA contributes to colorectal cancer migration by inducing epithelial-mesenchymal transition. Oncol Lett 8: 869-875, 2014.

239 Lipsyc $M$ and Yaeger R: Impact of somatic mutations on patterns of metastasis in colorectal cancer. J Gastrointest Oncol 6: 645-649, 2015.

240 Tie J, Lipton L, Desai J, Gibbs P, Jorissen RN, Christie M, Drummond KJ, Thomson BN, Usatoff V, Evans PM, Pick AW, Knight S, Carne PW, Berry R, Polglase A, McMurrick P, Zhao Q, Busam D, Strausberg RL, Domingo E, Tomlinson IP, Midgley R, Kerr D and Sieber OM: KRAS mutation is associated with lung metastasis in patients with curatively resected colorectal cancer. Clin Cancer Res 17: 1122-1130, 2011.

241 Kemeny NE, Chou JF, Capanu M, Gewirtz AN, Cercek A, Kingham TP, Jarnagin WR, Fong YC, DeMatteo RP, Allen PJ, Shia J, Ang C, Vakiani E and D'Angelica MI: KRAS mutation influences recurrence patterns in patients undergoing hepatic resection of colorectal metastases. Cancer 120: 3965-3971, 2014.

242 Yaeger R, Cowell E, Chou JF, Gewirtz AN, Borsu L, Vakiani E, Solit DB, Rosen N, Capanu M, Ladanyi M and Kemeny N: RAS mutations affect pattern of metastatic spread and increase propensity for brain metastasis in colorectal cancer. Cancer 121: 1195-1203, 2015.

243 Minardi D, Lucarini G, Milanese G, Di Primio R, Montironi R and Muzzonigro G: Loss of nuclear BAP1 protein expression is a marker of poor prognosis in patients with clear cell renal cell carcinoma. Urol Oncol 34: 1-8, 2016.

244 Ohno Y, Tachibana M, Kawamura T, Yoshioka K, Aoyagi T, Ohori M, Namiki K, Sakamoto N, Nakagami Y, Hatano T, Akimoto $\mathrm{S}$ and Nishimura T: Characterization and gene expression analysis of novel matched primary and metastatic renal cell carcinoma cell lines. Oncol Rep 20: 501-509, 2008.

245 Gerlinger M, Rowan AJ, Horswell S, Larkin J, Endesfelder D, Gronroos E, Martinez P, Matthews N, Stewart A, Tarpey P, Varela I, Phillimore B, Begum S, McDonald NQ, Butler A, Jones D, Raine K, Latimer C, Santos CR, Nohadani M, Eklund AC, Spencer-Dene B, Clark G, Pickering L, Stamp G, Gore M, Szallasi Z, Downward J, Futreal PA and Swanton C: Intratumor heterogeneity and branched evolution revealed by multiregion sequencing. N Engl J Med 366: 883-892, 2012.

246 Huang Y, Gao S, Wu S, Song P, Sun X, Hu X, Zhang S, Yu Y, Zhu J, Li C, Qin Z, Xie L, Yao Q, Tang A, Li Z, Guo G, Wan S, Dong P, Sun L, Li W, Wang D, Gui Y, Yang H, Zhou F, Zhang X and Cai Z: Multilayered molecular profiling supported the monoclonal origin of metastatic renal cell carcinoma. Int $\mathrm{J}$ Cancer 135: 78-87, 2013.

247 Kapur P, Christie A, Raman JD, Then MT, Nuhn P, Buchner A, Bastian P, Seitz C, Shariat SF, Bensalah K, Rioux-Leclercq N, Xie XJ, Lotan Y, Margulis V and Brugarolas J: BAP1 immunohistochemistry predicts outcomes in a multiinternational cohort with clear cell renal cell carcinoma. J Urol 191: 603-610, 2014.

248 Kerschbaumer J, Bauer M, Popoyscaia M, Grams AE, Thome $\mathrm{C}$ and Freyschlag CF: Correlation of tumor and peritumoral edema volumes with survical in patients with cerebral metastases. Anticancer Res 37(2): 871-875, 2017.

Received December 28, 2017

Revised February 20, 2018

Accepted February 22, 2018 